Dionys Van Gemert ${ }^{\star}$, Sven Ignoul, Kris Brosens and Eleni-Eva Toumbakari

\title{
Consolidation and Strengthening of Historical Masonry by Means of Mineral Grouts: Grout Development
}

\begin{abstract}
Mass consolidation of stone and brick masonry is considered, with exclusion of pure crack repair. Damage and specific failure mechanisms in multiple leaf masonry are presented. The aims of consolidation are explained, and the inherent advantages and disadvantages of distinct strengthening and consolidation techniques are given. An historical overview of consolidation methods and of development of consolidation grout materials is given, which explains how technology evolved to the actual procedures.
\end{abstract}

Keywords: three-leaf masonry, collapse mechanism, consolidation, injection grouts, modeling

DOI 10.1515/rbm-2015-0004

\section{Introduction}

Environmental and mechanical degradation processes have great impact on the load carrying capacity and on the structural behavior of brick and block masonry. Masonry shows distinct failure mechanisms, for which specific measures are needed to counteract these collapse mechanisms. Constriction and reinforcement rods are wellknown classical strengthening techniques. However, special injection grouts and injection technologies have been developed since the 1990s to enable an appropriate consolidation of degraded masonry, with respect for the authenticity and for the monumental value of the masonry in the context of the monument, as requested by the Charter of Venice [1]. Extensive scientific research was executed parallel with the development of the grouting

\footnotetext{
*Corresponding author: Dionys Van Gemert, Triconsult nv, Lindekensveld 5 bus 3.2, B-3560 Lummen, E-mail: dionys.vangemert@bwk.kuleuven.be

Sven Ignoul, Kris Brosens, Triconsult nv, Lindekensveld 5 bus 3.2, B-3560 Lummen

Eleni-Eva Toumbakari, Ministry of Culture, Vas. Konstantinou 2 - Maroussi, 15122 Athens
}

technique in restoration practice: the interaction between practice on site and scientific research produced a constant improvement of understanding and perception as well as enhanced procedures and injection grouts.

To develop and use structural consolidation techniques, the designer must start from the study and thorough understanding of the real nature and stress-strain behavior of masonry. Masonry is a composite material, made of stones and mortar, bricks and mortar, or stones, bricks and mortar. Three-leaf masonry is used all over the world in ancient masonry constructions (Figures 1 and 2). The parament (wythe) may be composed of bricks or stones; the core may be composed of stone or brick rubble with mortar filling. The stones can be uncoursed or (semi-) dressed. Figure 3 gives a schematic picture of three-leaf masonry. The mortar used as laying mortar in the wythes, or as filling mortar in the rubble stone, is the regional traditional masonry mortar: lime mortar or mud mortar. In lime mortars the lime binder to limestone or siliceous aggregate weight ratio shows a wide variation between $1 / 9$ and 2/ 5. Mud mortar contains up to 50 weight percent of clay and silt, mixed with limestone or siliceous aggregates [2].

Not only the nature of mortar and stones can account for the type of deterioration of the masonry but also the structural lay-out plays an important role. The deterioration in regular brickwork masonry differs from that in a wall, composed of an inner and outer leaf of natural stone, with a rubble masonry core in between.

Degradation of the composite material brick or stone masonry is caused by several deterioration phenomena, which can be categorized into different main types. Physical deterioration is the damage caused by temperature variations, fire, frost and thaw, erosion by water, corrosion of metal parts in the wall, dust. Physico-chemical deterioration phenomena are the swelling due to water absorption, crystallization or hydration pressures in the pores at crystallization of salts or hydration of crystals. Chemical corrosion is mainly the formation of gypsum due to atmospheric pollution. At last, we distinguish biological deterioration, caused by micro-organisms, plants, men.

Deterioration phenomena appear in the mortar as well as in the stones. As a result, the quality of both and the quality 


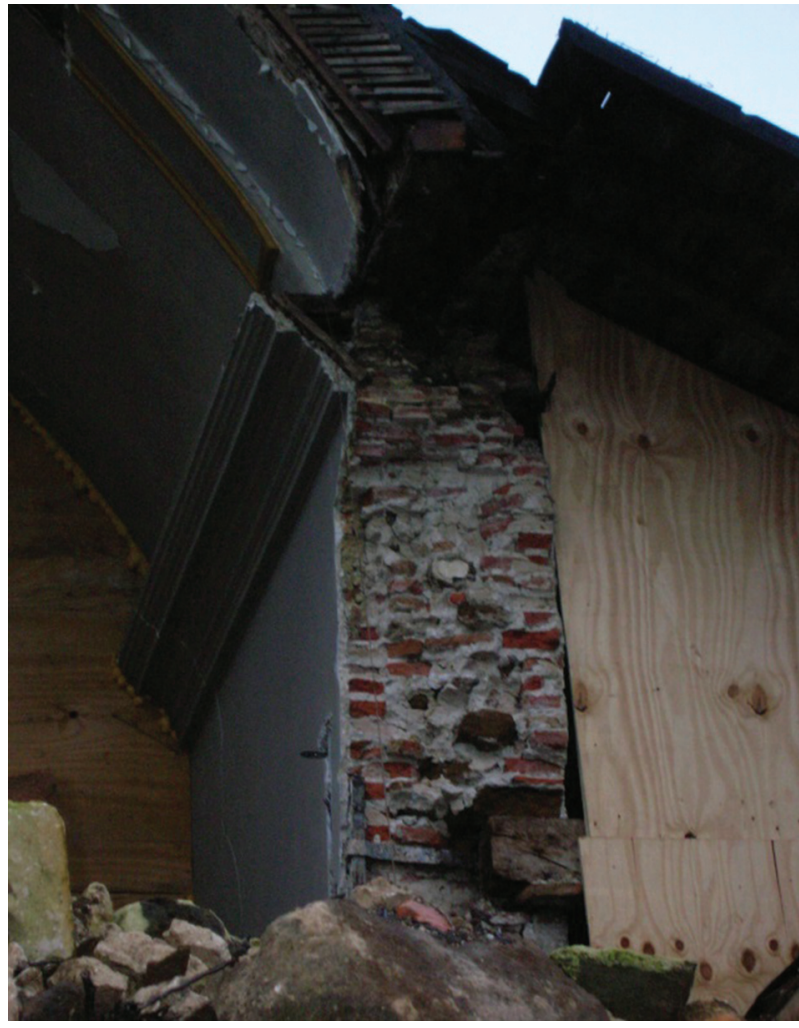

Figure 1 Three-leaf masonry with brick wythes [3]

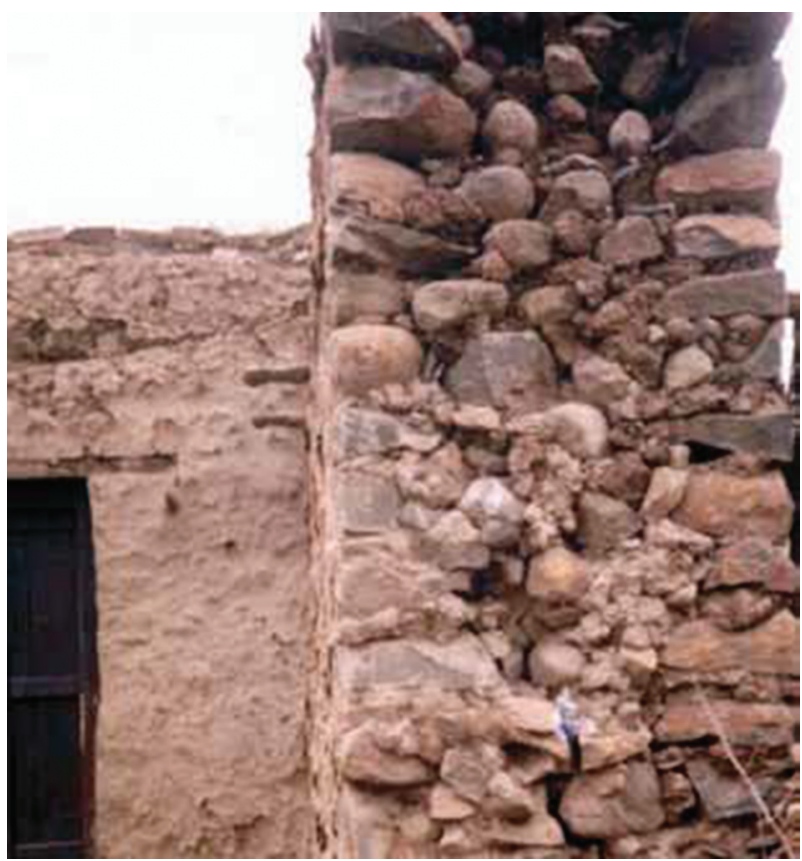

Figure 2 Uncoursed rubble stone exterior wythes with stone rubble core with mud mortar [4]

of the bond between stone and mortar diminish. The mechanical action on the masonry walls normally causes distributed vertical compressive stresses in the masonry, but at every discontinuity such as cracks, holes and pores,
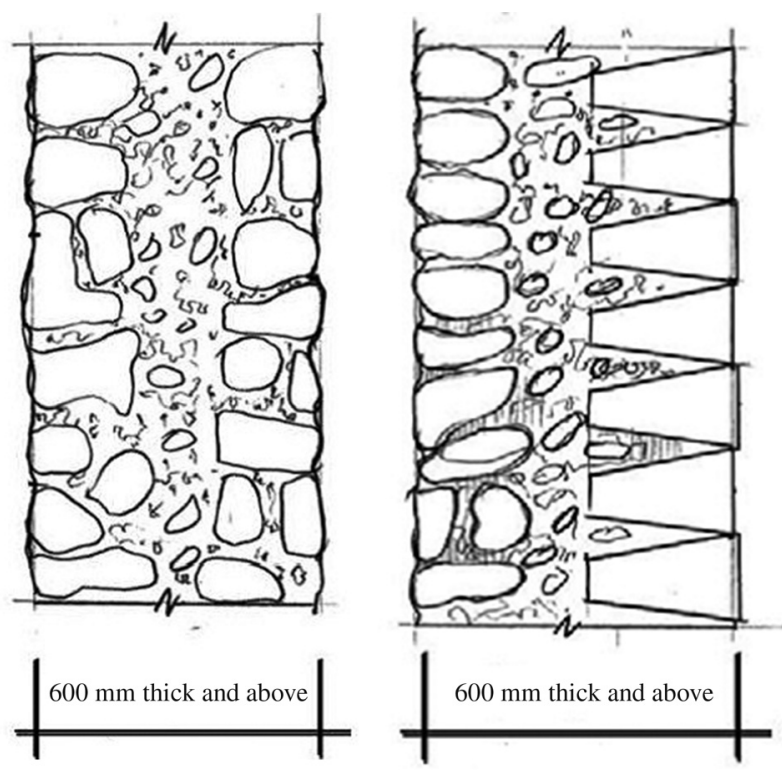

Figure 3 Scheme of three-leaf uncoursed rubble stone masonry wall (left) and a semi-dressed stone wall (right) [4]

interfaces between stones and mortar, also tensile stresses will appear [5]. Their magnitude is of the same order as the compressive stresses. The tensile stresses can cause cracking or micro-cracking in the stones, the mortar or in the bond between them. This cracking can be intensified by vibrations, shocks, wind loads, etc. It must be stressed that compressive stresses are mostly not harmful to masonry, except in some rare cases where buckling might occur or in arches and vaults with excessive crack openings.

Mechanical actions on the structural elements as well as degradation mechanisms influenced the structural built up of multiple leaf masonry. In earthquake-sensitive areas, the masonry was strengthened with timber or brick bands to enhance the wall stability in both uncoursed random rubble and semi-dressed masonry (Figure 4).

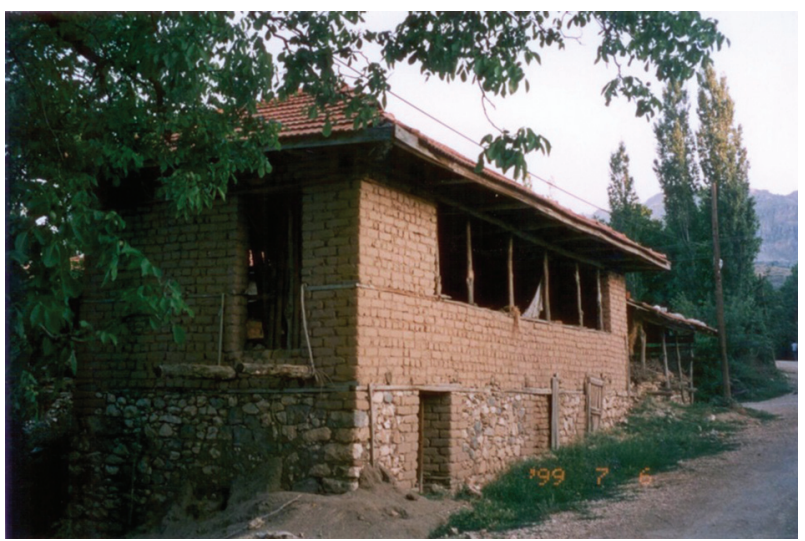

Figure 4 Timber bands in rubble stone masonry of basement and in mud brick masonry of first level (Ağlasun (TR), 1999) 
In Belgium, earthquakes are not a major problem. Although the standard NBN EN 1998:2004 also applies in Belgium, the Belgian national application document NBN EN 1998 NAD:2011 indicates that in about 90\% of Belgian territory the peak ground acceleration is lower than $0.05 \mathrm{~g}$, and that for usual buildings and usual soil conditions the seismic risk is negligible. Therefore, timber or brick strengthening bands are not present in three-leaf masonry in Belgium (Figure 5). However, this does not mean that no damage or collapses are happening in Belgium (Figures 5 and 6).

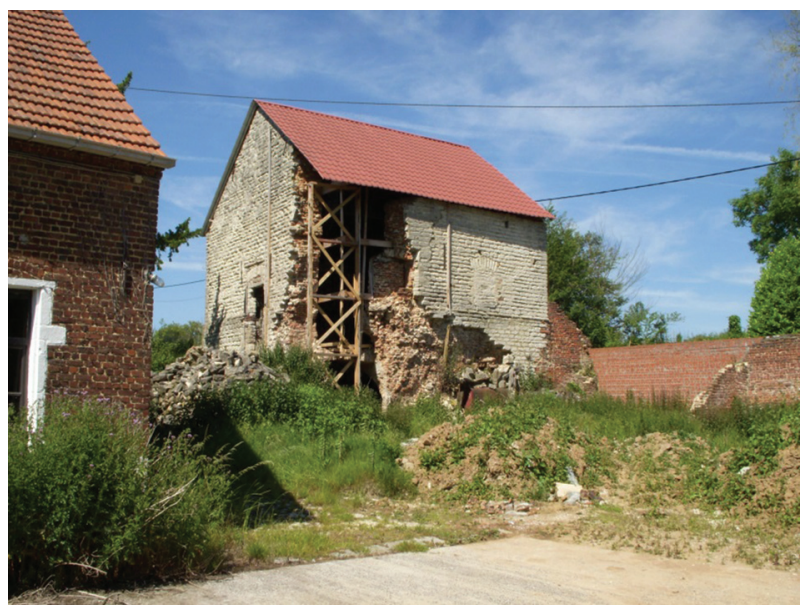

Figure 5 Semi-dressed three-leaf masonry in Donjon of monumental farm in Oppem (B), 2014

The choice of the methods and products for consolidation must be determined by the type and degree of degradation. Having in mind that tensile stresses are causing masonry failure, it is evident that every strengthening method must introduce elements or systems, capable of withstanding these tensile stresses. Grouted anchors and injected grouts are potential methods, but each of them has its specific application fields, and design will always be problem oriented. Sometimes they are alternatives, sometimes they are complementary, but sometimes it will be only one of the two that offers an appropriate solution.

Guidelines for structural engineering seismic analysis and design techniques focus on building displacement rather than forces as the primary parameter for the characterization of seismic performance. The building is approached as an assembly of its individual components. Force-deformation properties (e.g., elastic stiffness, yield point, ductility) control the behavior of wall panels, beams, columns, and other components. The component behavior, in turn, governs the overall displacement of the building and its seismic performance. Thus, the evaluation of the effects of damage on building performance must concentrate on how component properties change as a result of damage [6].
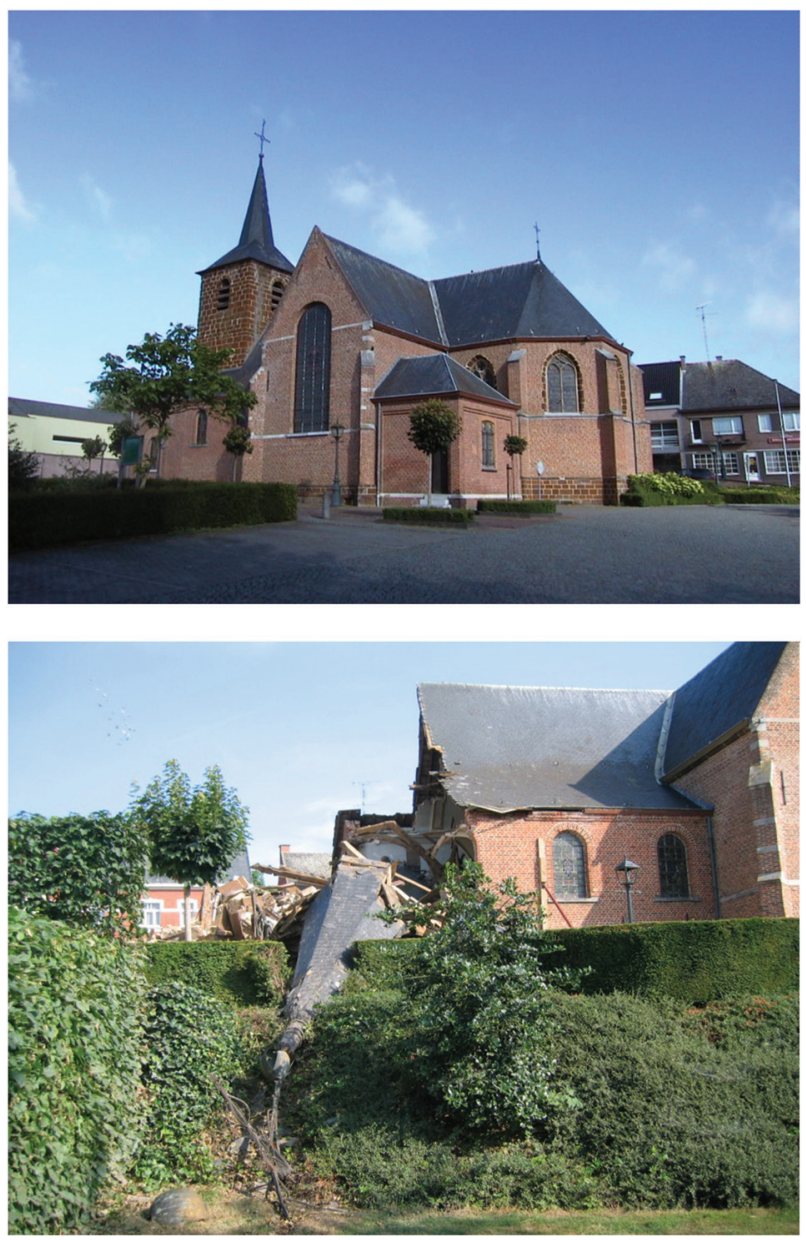

Figure 6 Church tower at Meldert (B) before July 7 (above), 2006, and after (below)

An extensive research program was executed at KU Leuven to understand three-leaf masonry structural behavior to develop appropriate injection grouts for its consolidation and to study the behavior after injection. Results of investigations and progress have been published over the years in Restoration of Buildings and Monuments. [7-10]. This paper describes the evolution of grout design and presents results of the evolution of grout properties as a function of two-year exposure at high $(\geqslant 96 \%)$ and moderate $(\geqslant 85 \%)$ relative humidity exposure conditions [11]. The condition of lower relative humidity affects all masonries, especially foundation masonry becoming exposed during and after archaeological excavations.

\section{Structural behavior of three-leaf masonry}

A typical collapse mechanism is happening in multiple leaf masonry. This mechanism is primarily caused by 
damage accumulation and creep under high load [12]. Theoretically, the vertical load is distributed over the full section of the wall (Figure 7). In most cases, the stiffness of the parament masonry will be higher than the stiffness of the rubble masonry in the core. The paraments will hinder the shortening of the core, by which the paraments will take over part of the load on the core (Figure 8). To duck out of these increased loads, the paraments try to shorten by buckling (Figure 9). As long as the adhesion between core and parament is satisfactory high, the paraments will not buckle and the three-leaf wall keeps its strength. However, the different deterioration actions weaken the mortar in the core, as well as the bond between paraments and core. Once the bond is too weak, the paraments will buckle, and the load moves back to the core, increasing the stresses in the core (Figure 10). The core masonry is not strong enough to carry the extra load and will further deform to move the loads back to the paraments. This shifting of loads continues until the paraments completely buckle, or until the core masonry fails by shear along the weakest plane (Figure 11).

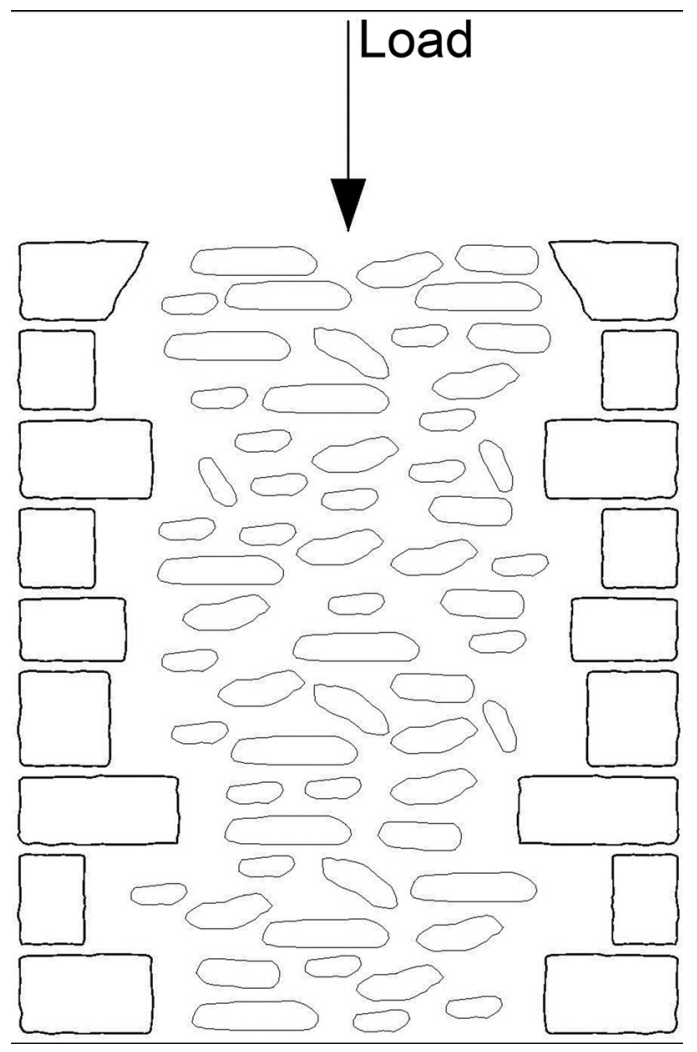

Figure 7 Load carried by full cross section

Figure 12(a)-(c) shows the collapse of the ruins of a church in Tienen (B): the shear planes in the columns are clearly visible.
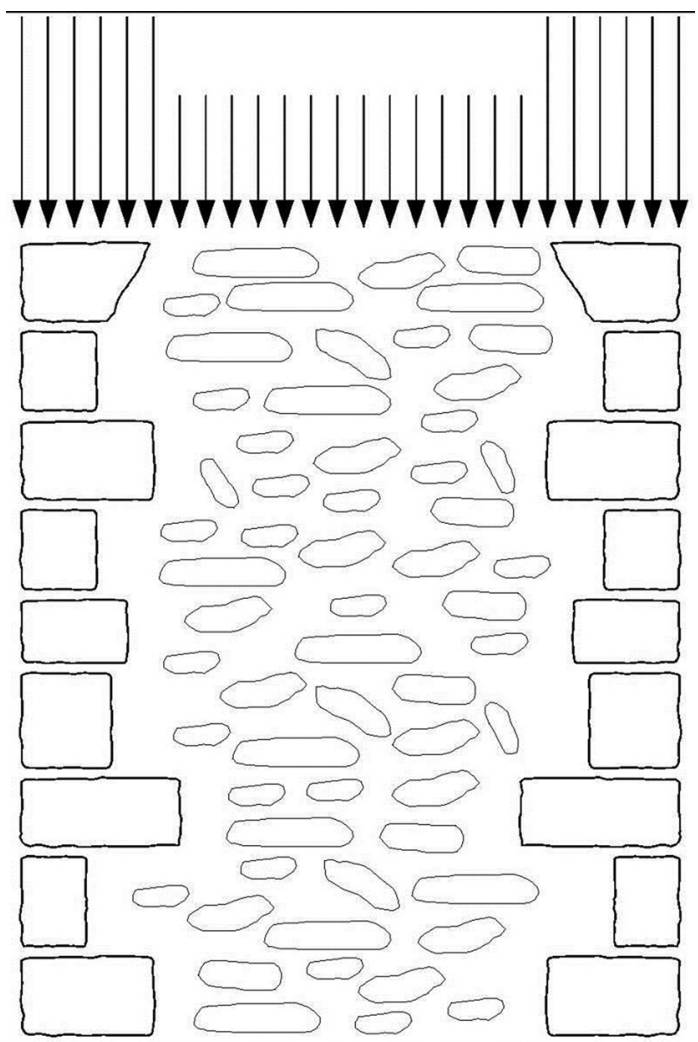

Figure 8 Stress distributions between paraments and core

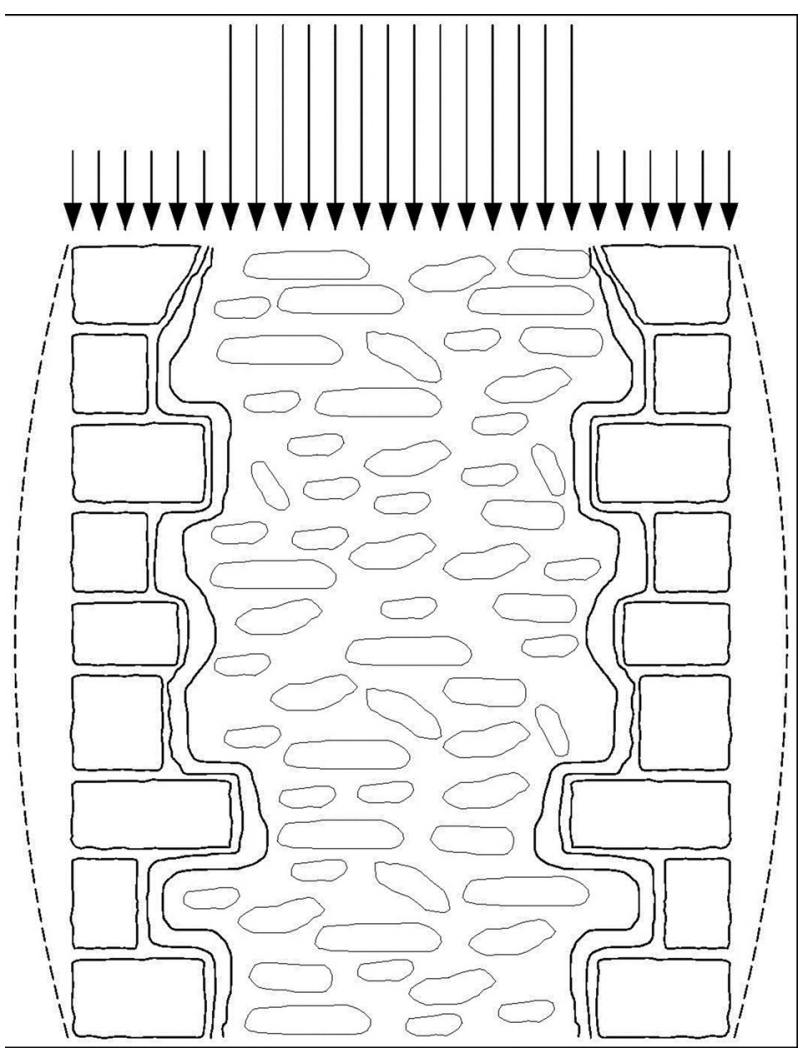

Figure 9 Buckling of paraments under increased load 


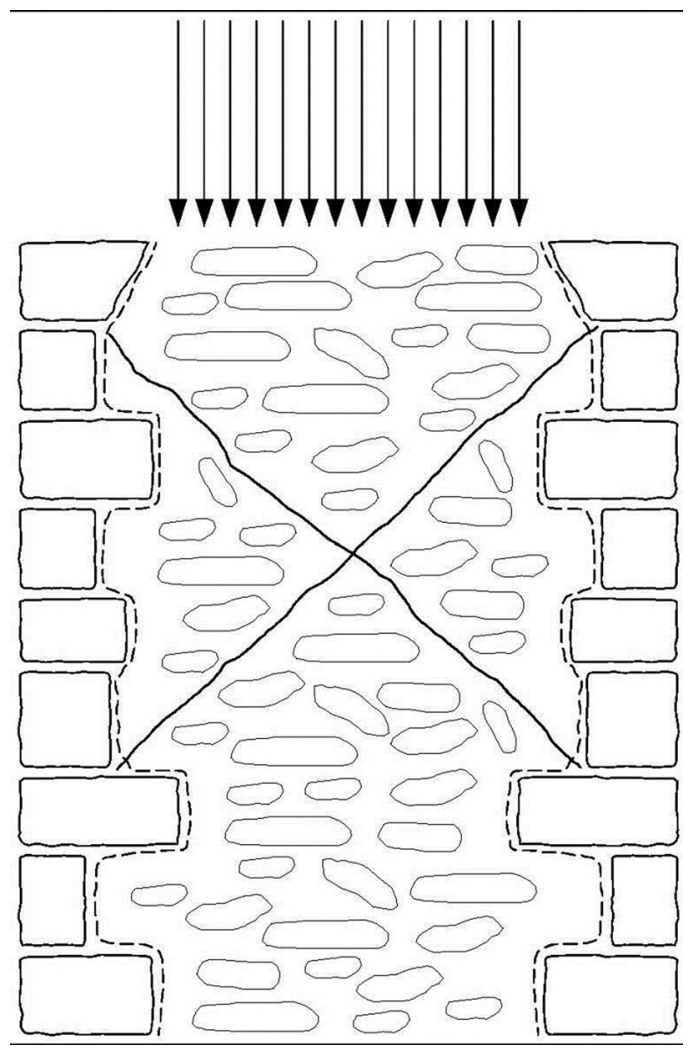

Figure 10 High stresses on core masonry after debonding of paraments

Debonding of parament from core masonry is clearly visible in Figure 13, a cross-section view of the three-leaf wall of the monumental tower 'Maagdentoren' at Zichem (B). Partial collapse here started at a weakened zone at the ground level of the tower (Figure 14(a)). The triangular wall part on top of the collapse rubble (Figure 14(b)) was originally situated at mid height of the tower. Inclined, weak shear planes are indicated in Figure 14(c).

The above collapse mechanism also indicates how to counteract it: because discontinuities and holes initiate crack formation in the masonry, strengthening or consolidation must remove such discontinuities. The lower stiffness of the core masonry causes overloading of the paraments: consolidation must enhance stiffness of the core. Final collapse is linked to buckling of the paraments: strengthening and consolidation must provide a better adhesion between parament and core or must provide mechanical anchoring of paraments to core. The failure plane is diagonally through the masonry: the consolidation provides improved strength (cohesion) of the mortar, by which the core masonry gets enhanced shear strength.

The different strengthening and consolidation principles are as follows:
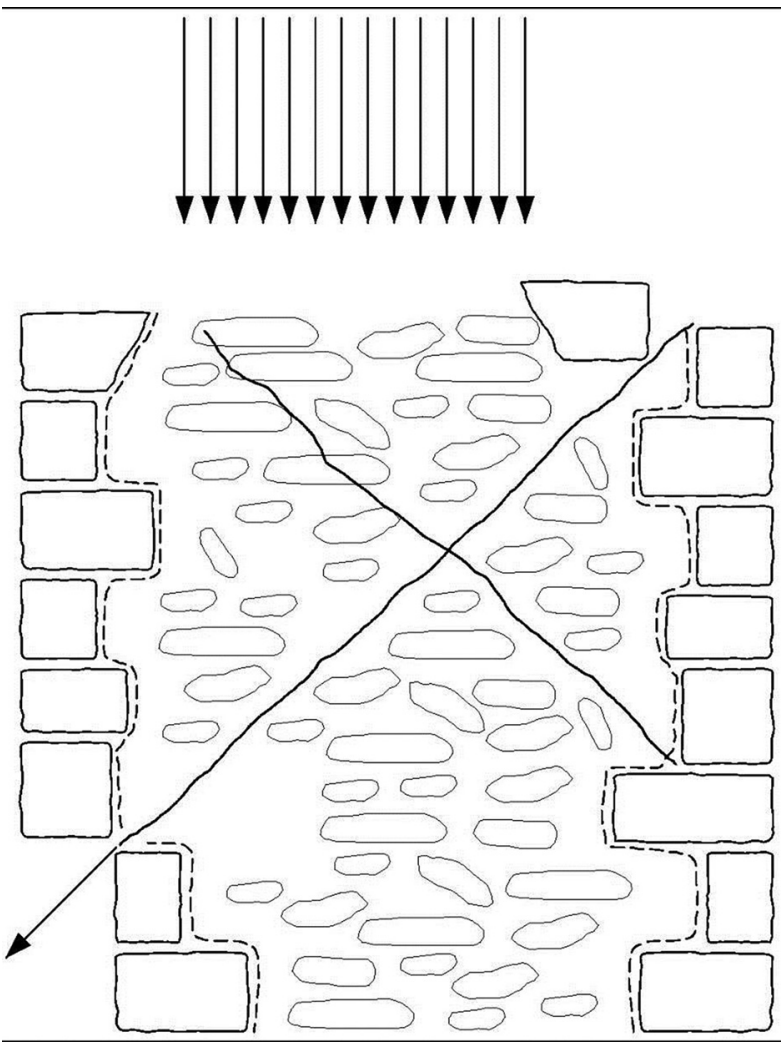

Figure 11 Failure of core masonry by shear along weakest planes

- filling of holes and cracks

- enhancement of stiffness of core masonry

- preventing buckling of paraments

- enhancement of cohesion and strength of core masonry

An additional benefit of strengthening and consolidation is the improved homogeneity of the masonry. The statistical distribution of the strength $\mathrm{R}$ becomes more concentrated around the mean value (Figure 15) [8].

In the development of consolidation techniques during the last decades, increased attention has been devoted to safeguarding the authenticity of the historical material and of the monumental value of the masonry construction, to comply with the general principles stated in different restoration charters, of which the best-known is the Charter of Venice (1964) [1]. Compatibility and reversibility are key principles in the charters.

In earthquake-sensitive areas, masonry must be able to withstand shear actions. The criteria for shear resistance are the same as for vertical normal stress loading: avoiding buckling of paraments and increasing cohesion and adhesion of core masonry. 


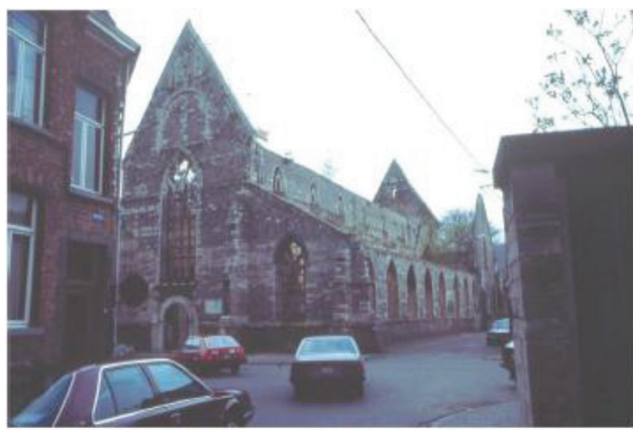

(a)

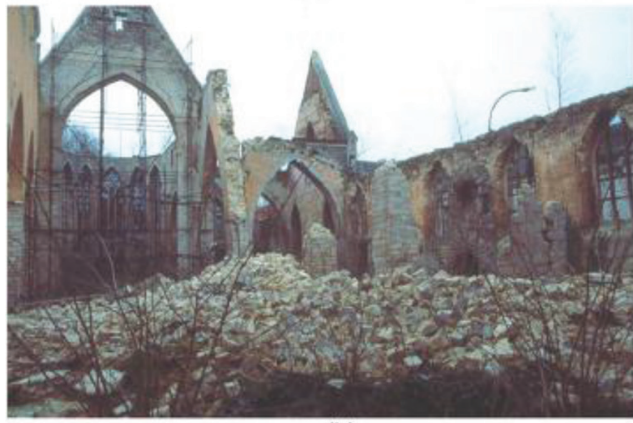

(b)

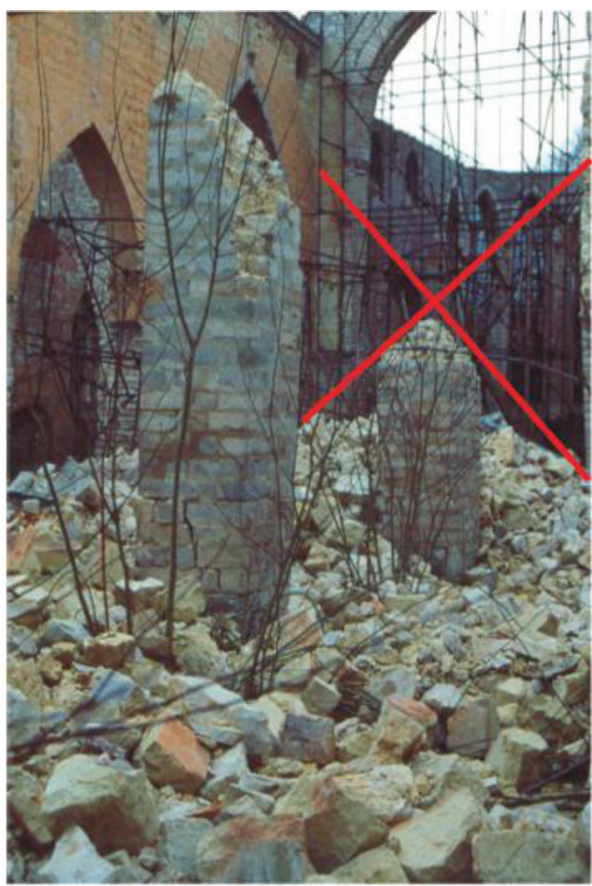

(c)

Figure 12 (a) Ruin of church 'Paterskerk' at Tienen, after fire on September 22, 1976. Situation in 1989 (Origins thirteenth-fourteenth century). (b) Collapse of south wall of nave in 1989. Successive wall collapses till conservation as ruin in 1996-1997. (c): Failure of multiple leaf masonry along $\pm 45^{\circ}$ planes of weakest shear strength (Paterskerk, Tienen, 1989)

\section{Consolidation grouts}

\subsection{History of consolidation grouting for masonry}

Strengthening of masonry was done initially by means of grouted anchors [10]. However, the grouted anchor system is a system on which the saying "it can't do any harm and it may do some good" is not applicable. If the anchoring system is not designed in the proper way, it will further lower the already low strength of the treated masonry. This was clearly shown in several experiments [13], where due to the drilling of holes for the anchors the strength was lowered with about $10 \%$. A clear picture of this situation is given in Figure 16 [13] found in experiments executed at the University of Karlsruhe (D).

Guided by the Venice Charter, and driven by the above negative experiences, impregnation and grouting or injection of masonry has been developed in the period 1975-1985 for the consolidation of masonry [10]. The grout must fill the voids and holes in the masonry to allow the force flow to be distributed uniformly over the masonry mass and thus avoiding splitting forces. Moreover the grout must increase the internal cohesion of the original mortar as well as the adhesion of the mortar to the stones. Most used for consolidation purposes at the beginning were solvent-free reactive epoxy resins. The first applications in Belgium were made at the strengthening of columns in the Cathedral of Our Lady at Antwerp (B) in 1979-1981 and at the consolidation of walls in the seventeenth century monument "Oud Gasthuis" at Herentals (B) in 1984 [14]. Some attempts were made to use polyurethane resins that formed elastic polymers inside the masonry. Through the addition of fillers, the mechanical characteristics could be changed in a wide range. Consolidation of stone with the method of methyl methacrylate impregnation in the form of solutions of monomer in alcohols, or by monomer impregnation under vacuum, is reserved to the restoration of statues and art objects. It needs a very strict process control, which is difficult to apply on the restoration site [5].

In 1986, M. Ullrich reported about one church tower, which had to be torn down because the resin-based grout, that had been injected 12 years before, was still not hardened and continued to drop out of the masonry [15].

This negative experience, combined with the cost of the resin grouts and the high consumption rate in masonry, forced designers to develop new consolidation 


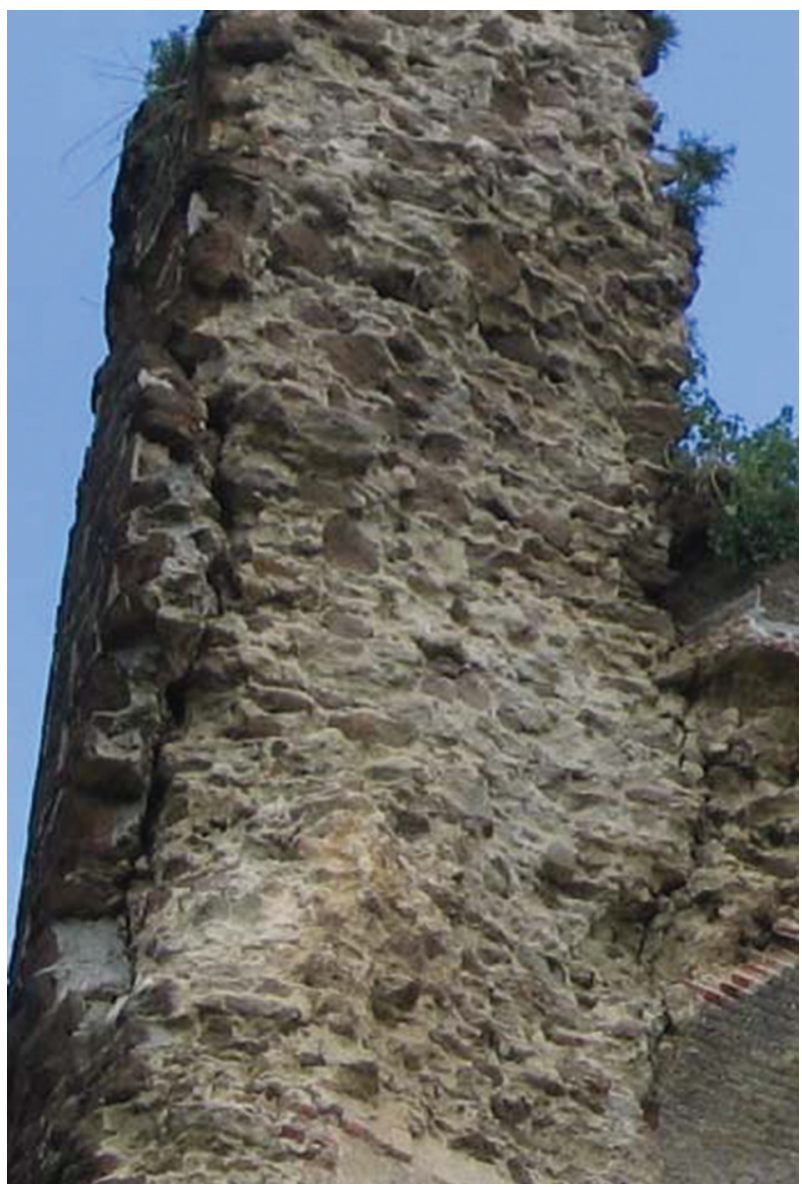

Figure 13 Debonded wythe in wall of cylindrical donjon tower 'Maagdentoren' (fourteenth century)

procedures and systems. Indeed, the volume rate of voids in masonry mounts up to $20-30 \%$. If a pure polymer such as epoxy resin is used, the technique becomes very expensive. Moreover, compatibility with the original masonry material is problematic at high consumption rates of resin. Therefore, mineral injection grouts have been developed, starting with a pure, normal cement binder with adapted mixing procedure [7] as an alternative for micro-cement. Due to the high strength and stiffness of the cement grout, softer alternatives were developed, based on combinations of lime, pozzolan and cement [8-11].

\subsection{Ternary lime-pozzolan-cement grouts}

The properties of blended lime-cement-pozzolan grouts have been studied thoroughly in the laboratory and on the site $[16,17]$. An overview of properties of polymer, cement and blended grouts is given in Ref. [8].

It is interesting to repeat some of the findings concerning the evolution with time of compressive strength and bending strength for different blended grouts, as well as concerning the adhesion or bond strength between the grouts and brick or stone. Tests were done on samples $40 \times 40 \times 160 \mathrm{~mm}$ according to the Belgian Standard NBN B14-208 for compression and bending, and with a Casagrande shear set-up under normal stresses of 0.1, 0.3 and 1.0 MPa.

Compositions are indicated as grout 1:3:0.45, indicating the composition in weight parts: 1 part of hydrated lime: 3 parts of Rheinisch Trass; 0.45 parts of Portland cement. The compositions represented in the Figures 17 and 18 contain $10 \%$ or $30 \%$ of cement in the total binder amount.

The development of strength at the beginning is due to and determined by the cement content. This is not surprising, because the hydraulic activity of the pozzolans only starts after about 4 weeks. In the mixes with $30 \%$ of cement, the initial strength is not related to the lime to pozzolan ratio. Only after 60 days a significant difference arises. After 180 days the compressive strength reaches about 10 to $12 \mathrm{MPa}$ for the $30 \%$ mixes. The evolution of the bending strength shows that a minimum of $30 \%$ of cement should always be present in the grout mix, because otherwise the tensile bending strength, which is also a measure for the bond strength, drops to zero after half a year. This is due to the delayed hydraulic reaction of the lime and the pozzolans, which chemically attacks the initial hydrated structure of the cement fraction, and exerts destructive forces on the hydrated cement skeleton [8].

The shear bond characteristics for a brick and a limestone substratum were tested in a Casagrande shear box apparatus, which enabled the measurement of shear stress versus slip under specific normal stresses. The general shear stress-slip curve is shown in Figure 19. The shear bond characteristics for a brick and a limestone substratum are given in Tables 1 and 2.

The grout composition is 1 part of lime to 3 parts of pozzolan, with $30 \%$ of cement, with addition of $0 \%$ (13b-0) or $10 \%(13 \mathrm{~b}-10)$ of silica fume; grout $\mathrm{Cb}-0$ is a pure cement grout. $\tau_{\mathfrak{u}}$ is the maximum shear bond strength at slip $s_{u}$ in the shear box test. The grouts were injected in test wallets (Figure 20), which were previously loaded in compression till cracking in the post peak zone. The test results are given in Table 3 [16].

From the results it is obvious that grout compressive strength is not the main factor controlling the strength of the grouted walls. Of much more importance are the stiffness of the grouts and their bond traction and shear bond strength. These grout properties limit the horizontal deformability of the different leaves of the masonry, thus 
(a)

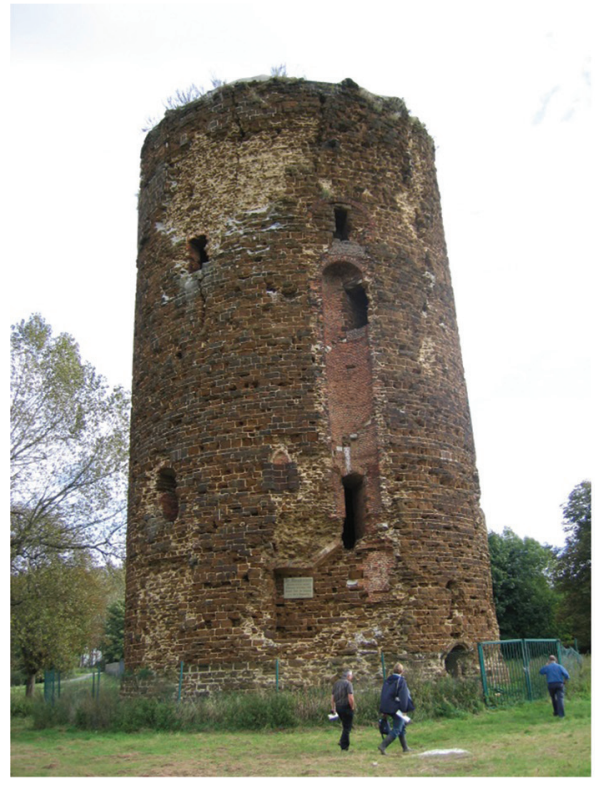

(b)

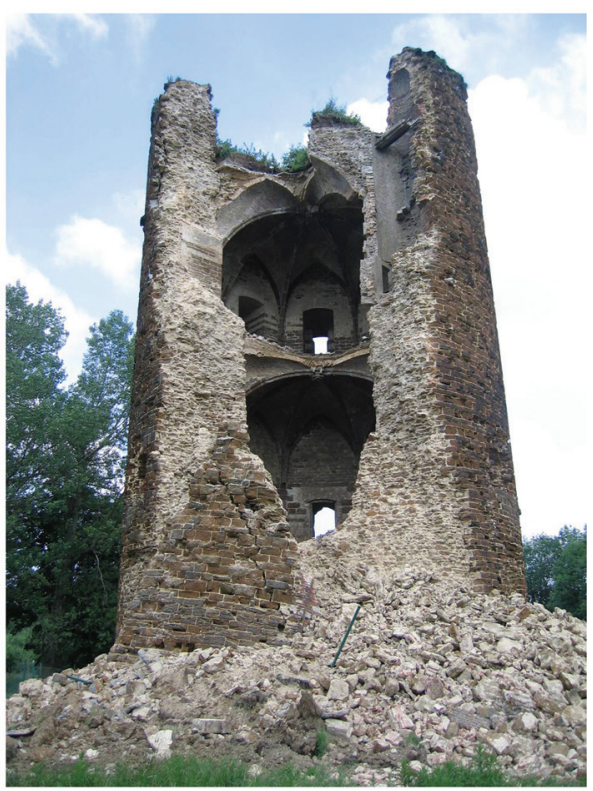

(c)

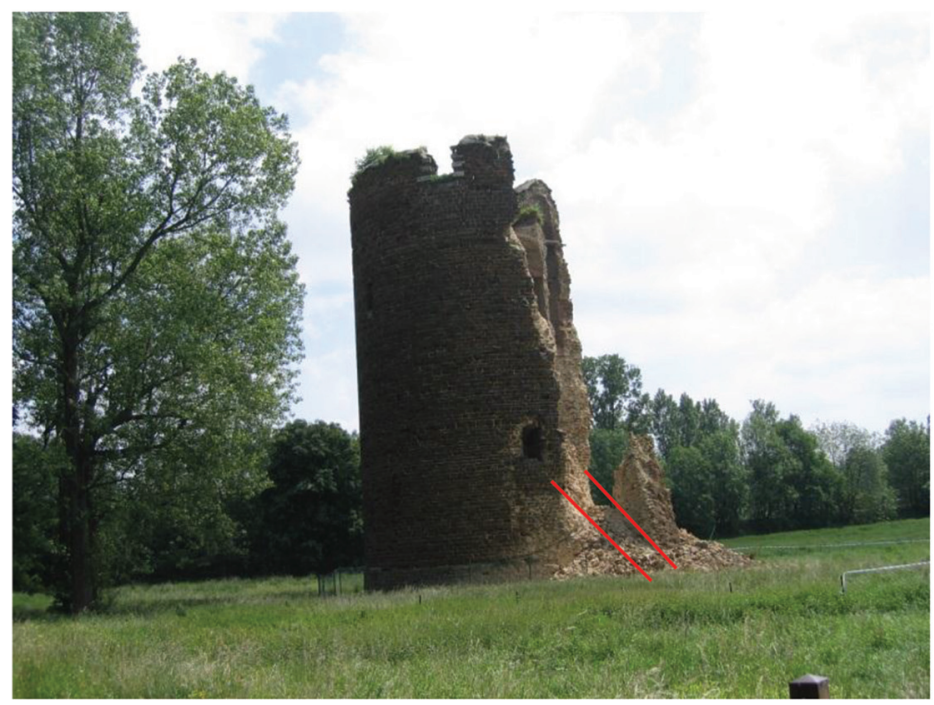

Figure 14 (a) Donjon 'Maagdentoren', situation September 2005. (b) Maagdentoren, after partial collapse on June 1, 2006. (c) Shear planes in masonry

reducing crack opening, and increasing the vertical compressive stress required to accelerate the transverse horizontal crack opening, which causes collapse of masonry. The test wallets with transverse leafs were intended to simulate the effect of transverse walls, connecting the external leafs in three-leaf walls.

Similar comparison was made for wallets with the same composition, but loaded in diagonal compression (split-tension test), to simulate wall behavior under shear loading, Figure 21 [16].
Results of diagonal compression tests before and after consolidation injection are summarized in Table 4.

Diagonal tension strength was calculated from the maximum applied load $\mathrm{P}$ and the vertical cross sectional area $A_{v}$, using the conventional expression $f_{w t}=2 P / \pi A_{v}$.

It was observed that horizontal deformations and cracking were restricted up to $70 \%$ of strength after injection. After that, cracking evolves in an accelerated manner, but total deformation at failure is also increased. Deformation absorption capacity is increased. 

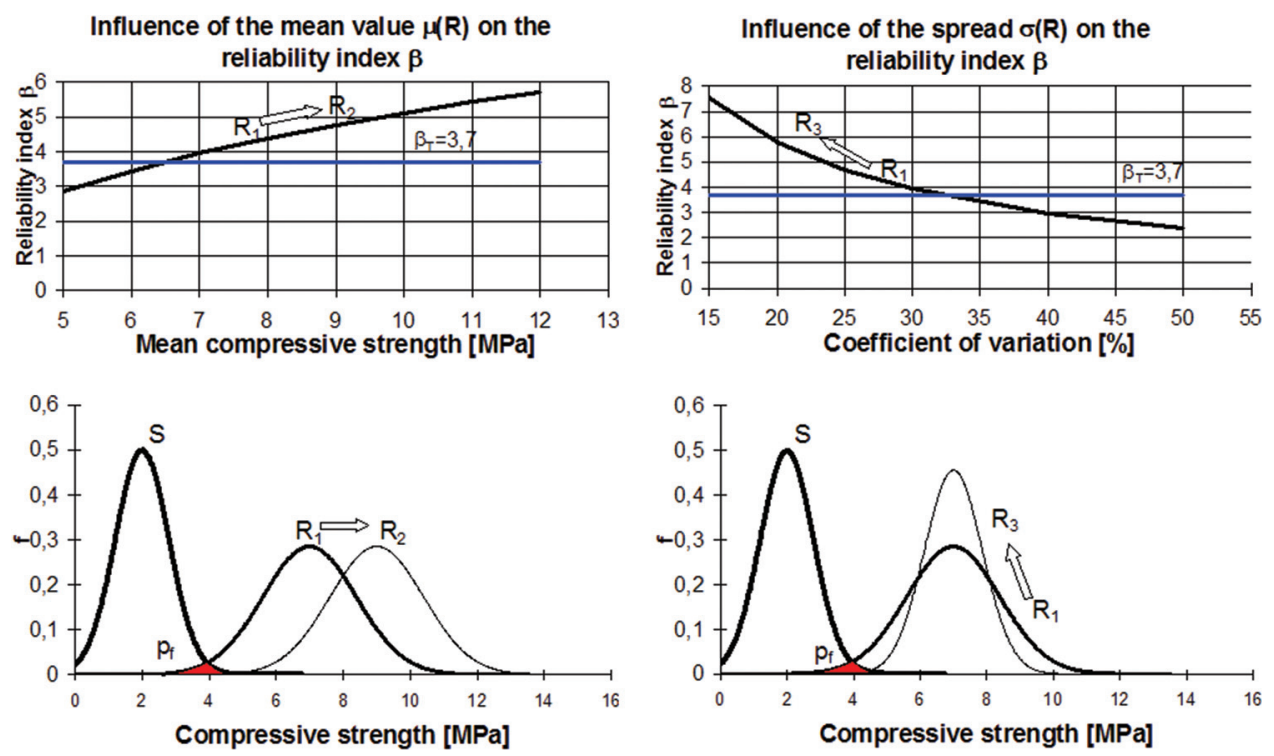

Figure 15 Improvement of safety factor at increased strength (R2 > R1, left figures) and at better homogeneity (distribution R3 narrower than distribution R1, right figures)

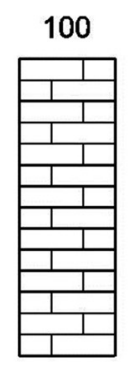

type: 1

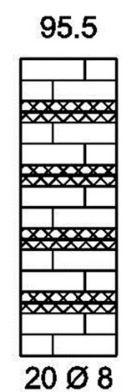

2

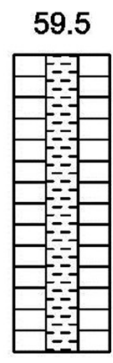

3

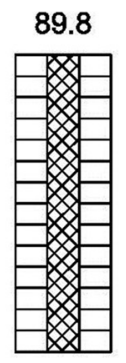

4

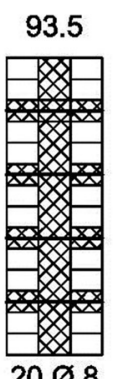

$20 \varnothing 8$

5

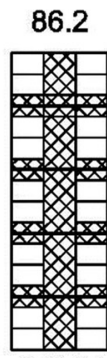

$4 \varnothing 14$

6

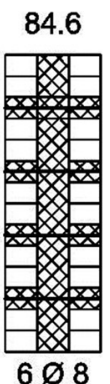

7

Figure 16 Decrease of strength due to drilling of anchors

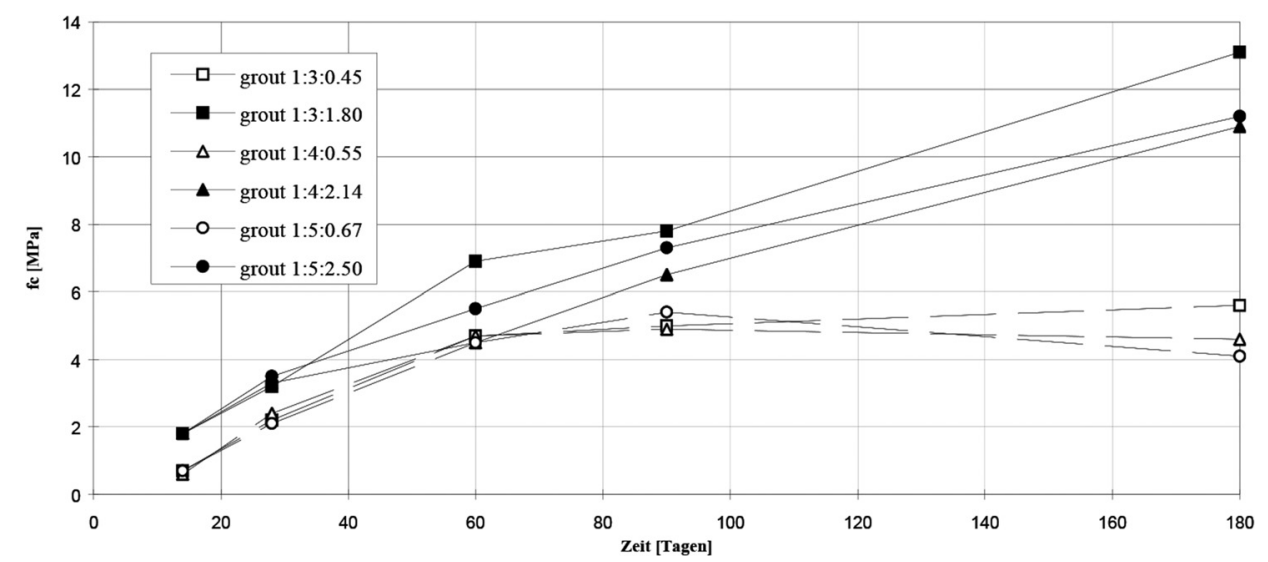

Figure 17 Time evolution of compressive strength of blended grouts 


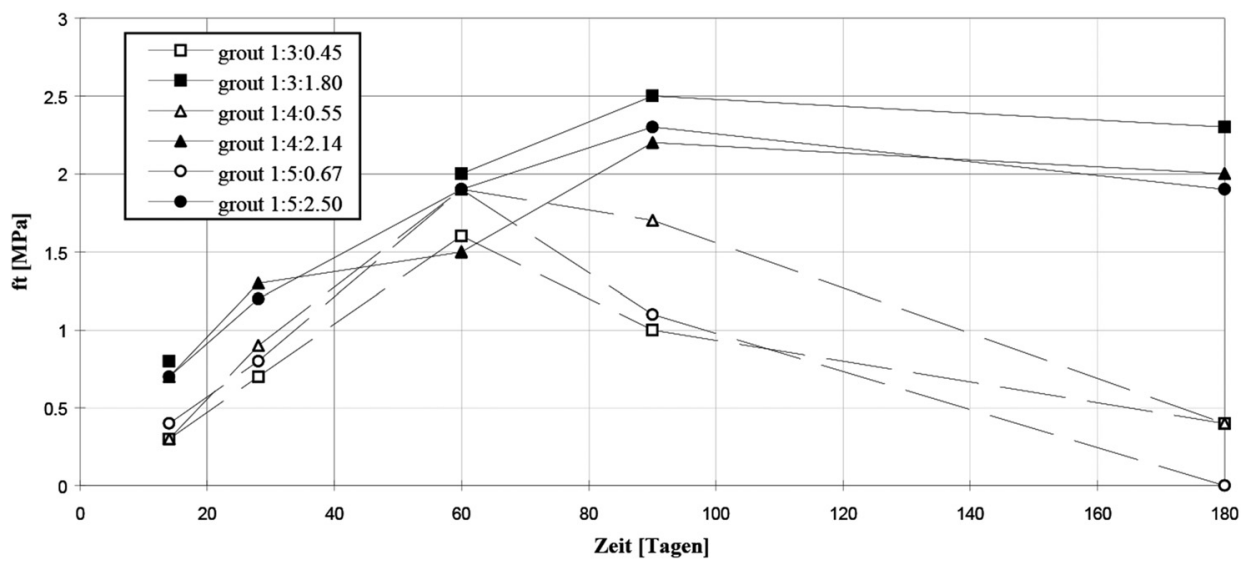

Figure 18 Time evolution of bending strength of blended grouts

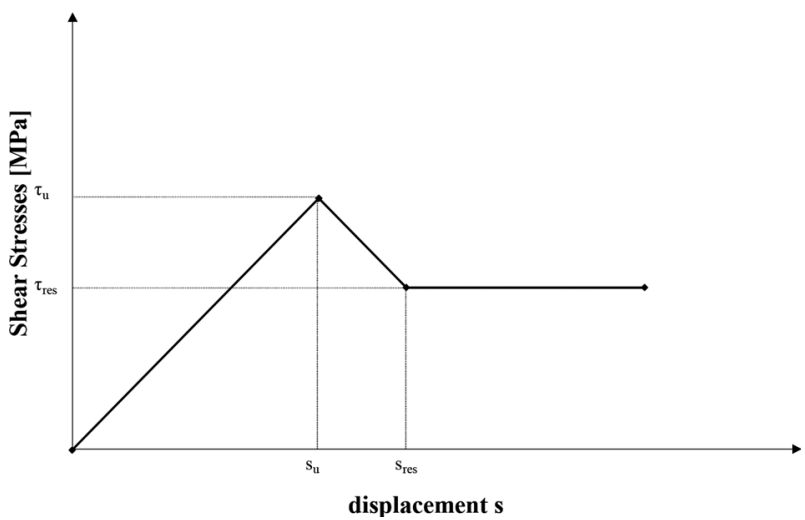

Figure 19 Shear stress-slip relation for grout-substratum interface

Table 1 Shear bond characteristics for a brick substratum

\begin{tabular}{|c|c|c|c|c|c|c|}
\hline \multirow[t]{2}{*}{ Normal stress } & \multicolumn{2}{|r|}{$13 b-0$} & \multicolumn{2}{|c|}{$13 b-10$} & \multicolumn{2}{|r|}{$\mathrm{Cb}-0$} \\
\hline & $\tau_{u}$ & $\mathbf{s}_{\mathbf{u}}$ & $\tau_{u}$ & $\mathbf{s}_{\mathbf{u}}$ & $\boldsymbol{\tau}_{\mathbf{u}}$ & $\mathbf{s}_{\mathrm{u}}$ \\
\hline$(\mathrm{MPa})$ & $(\mathrm{MPa})$ & $(\mathrm{mm})$ & (MPa) & $(\mathrm{mm})$ & (MPa) & $(\mathrm{mm})$ \\
\hline 0.1 & 0.38 & 0.39 & 0.67 & 0.38 & 0.65 & 0.32 \\
\hline 0.3 & 0.68 & 0.39 & 0.99 & 0.37 & 1.01 & n.a. \\
\hline 1.0 & 0.84 & 0.50 & 1.13 & 0.31 & 1.98 & 0.75 \\
\hline
\end{tabular}

Table 2 Shear bond characteristics for a limestone substratum

\begin{tabular}{|c|c|c|c|c|c|c|}
\hline \multirow[t]{2}{*}{ Normal stress } & \multicolumn{2}{|r|}{$13 b-0$} & \multicolumn{2}{|c|}{$13 b-10$} & \multicolumn{2}{|r|}{$\mathrm{Cb}-\mathrm{O}$} \\
\hline & $\tau_{u}$ & $\mathbf{s}_{\mathbf{u}}$ & $\tau_{u}$ & $\mathbf{s}_{\mathbf{u}}$ & $\tau_{u}$ & $\mathbf{s}_{u}$ \\
\hline (MPa) & $(\mathrm{MPa})$ & $(\mathrm{mm})$ & (MPa) & $(\mathrm{mm})$ & (MPa) & $(\mathrm{mm})$ \\
\hline 0.1 & 0.44 & n.a. & 0.67 & n.a. & n.a. & n.a. \\
\hline 0.3 & 0.35 & 0.17 & n.a. & n.a. & n.a. & n.a. \\
\hline 1.0 & 0.83 & 0.33 & 1.12 & 0.54 & 1.19 & 0.22 \\
\hline
\end{tabular}

Note: n.a.: not available.

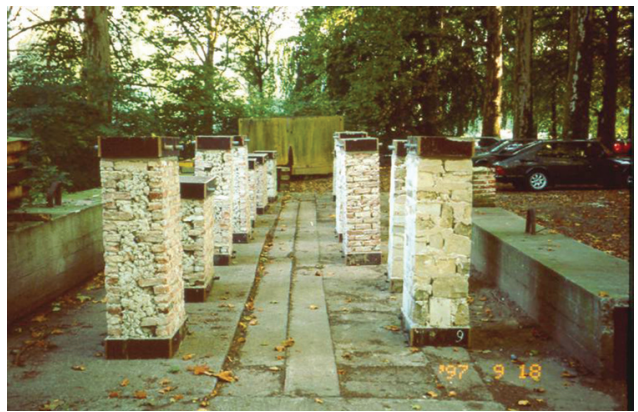

Figure 20 Three-leaf test wallets with brick or stone paraments, for vertical loading (tall wallets) and diagonal loading (short wallets in back of picture)

\subsection{Binary lime-cement grouts}

\subsubsection{Need for adapted consolidation grout}

The injectability of a mineral grout depends among other on the fineness of the dispersion of the binder particles in the water phase. The addition of stabilizers and superplasticizers prevents the dispersion from coagulation and segregation. In the framework of the restoration of Our Ladies Basilica in Tongeren (1999-2007), a profound research on lime-cement injection grouts could be made. Part of the restoration concerned the excavation of an archaeological cellar under the basilica, because the basilica was built on top of the remains of a Roman settlement dating back till 27 BC (Figure 22).

The foundation masonry was consolidated by means of grout injection and served to anchor the micropiles that were bored as new foundation system under the basilica.

Although the main objective concerning the consolidation and strengthening of the foundation masonry was 
Table 3 Strength of the walls under compression loading, before and after injection (B brick; C compression; $\mathrm{S}$ natural stone) (Wall size: $400 \mathrm{~mm} \times 600 \mathrm{~mm} \times 1,200 \mathrm{~mm}$ )

\begin{tabular}{|c|c|c|c|c|c|}
\hline & \multirow[t]{2}{*}{ Grout } & \multicolumn{2}{|c|}{ Modulus of elasticity (MPa) } & \multirow{2}{*}{$\begin{array}{r}f_{w c, 0} \\
(\mathrm{MPa})\end{array}$} & \multirow{2}{*}{$\begin{array}{l}f_{w c, i n j} \\
(\mathrm{MPa})\end{array}$} \\
\hline & & Before injection & After injection & & \\
\hline $\mathrm{BC} 1$ & $13 b-0$ & - & $2,238.2$ & - & 5.04 \\
\hline $\mathrm{BC} 2$ & $13 \mathrm{~b}-10$ & 729.6 & $1,564.9$ & 2.41 & 3.15 \\
\hline $\mathrm{BC} 3$ & $\mathrm{Cb}-0$ & & $1,404.8$ & 2.09 & 2.91 \\
\hline $\mathrm{BC} 4$ & $13 b-0$ & $1,097.6$ & $1,040.4$ & 2.18 & 3.00 \\
\hline BC5 (t.l.) & $13 b-0$ & $1,144.9$ & $1,170.2$ & 2.28 & 3.86 \\
\hline \multicolumn{2}{|c|}{ Average excl. BC1 \& BC5 } & 948.5 & $1,336.7$ & 2.23 & 3.02 \\
\hline \multicolumn{2}{|c|}{ Average excl. BC1, incl. BC5 } & 997.6 & $1,295.1$ & 2.24 & 3.23 \\
\hline $\mathrm{SC} 1$ & $13 b-0$ & 720.4 & $1,622.2$ & 2.02 & 3.25 \\
\hline $\mathrm{SC} 2$ & $\mathrm{Cb}-0$ & $1,138.7$ & $1,558.6$ & 2.07 & 3.36 \\
\hline SC3 (t.l.) & $13 b-0$ & $1,374.8$ & $1,187.8$ & 2.65 & 3.51 \\
\hline $\mathrm{SC} 4$ & $13 b-0$ & $1,443.3$ & $1,014.5$ & 2.71 & 3.29 \\
\hline \multicolumn{2}{|c|}{ Average excluding SC3 } & $1,100.8$ & $1,398.4$ & 2.27 & 3.30 \\
\hline \multicolumn{2}{|c|}{ Average including SC3 } & $1,169.3$ & $1,345.8$ & 2.37 & 3.35 \\
\hline
\end{tabular}

Note: (t.l. $=$ with transverse connecting leaves).

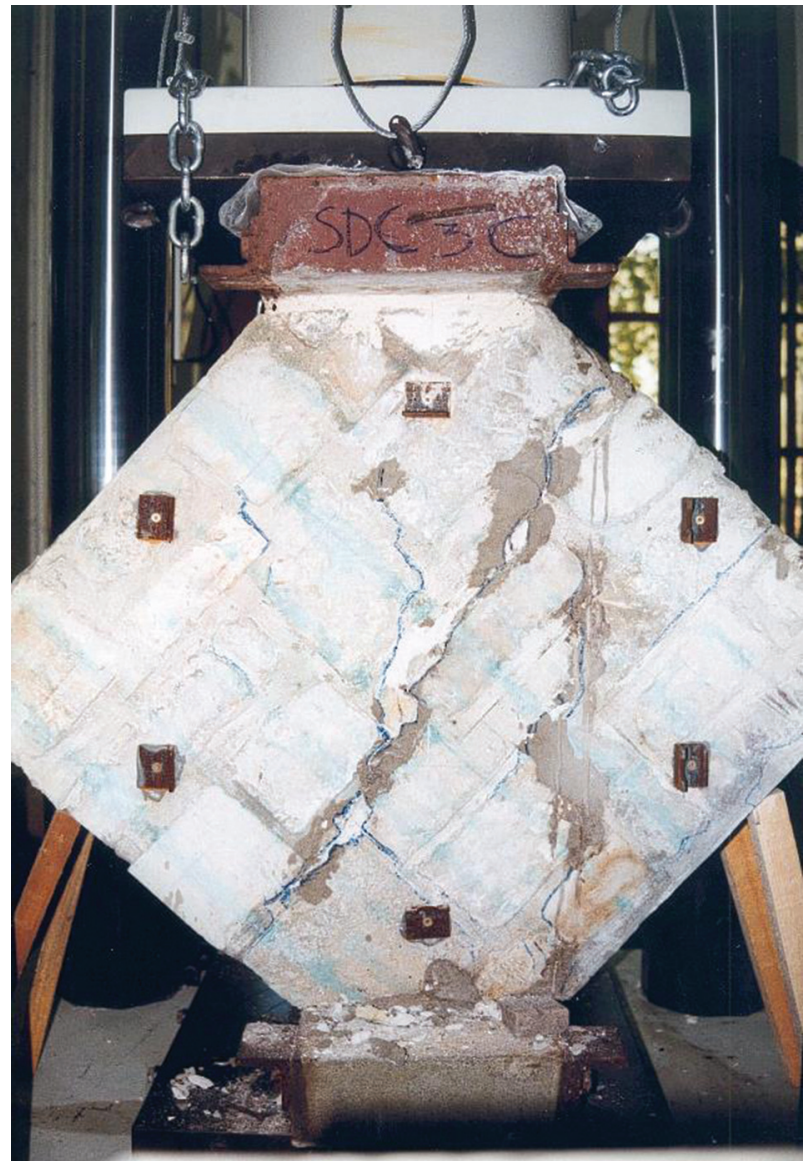

Figure 21 Diagonal compression test. Wallet dimensions: $800 \times 800 \times 400 \mathrm{~mm}$
Table 4 Diagonal tensile strength of original and injected wallets

\begin{tabular}{lrrrrr}
\hline & Grout & \multicolumn{2}{r}{$\begin{array}{r}\text { Deformability at ultimate } \\
\text { load }\end{array}$} & $\mathbf{f}_{\mathbf{w t}, \mathbf{0}}$ & $\mathbf{f}_{\mathbf{w t}, \text { inj }}$ \\
\cline { 3 - 5 } & & $\begin{array}{r}\text { Before } \\
\text { injection \%o }\end{array}$ & $\begin{array}{r}\text { After } \\
\text { (MPa) }\end{array}$ & (MPa) \\
& & 0.45 & 1.56 & 0.44 & 0.60 \\
\hline BDC1 & $13 \mathrm{~b}-0$ & 0.15 & 1.07 & 0.34 & 0.73 \\
BDC2 & $13 \mathrm{~b}-10$ & 0.13 & 1.02 & 0.35 & 0.75 \\
BDC3 & Cb-0 & 0.68 & 1.36 & 0.47 & 0.50 \\
SDC1 & $13 \mathrm{~b}-10$ & 0.13 & 1.17 & 0.34 & 3.36 \\
SDC2 & Cb-0 & 0.12 & 2.65 & 0.28 & 3.51 \\
SDC3 & $13 \mathrm{~b}-0$ & & & & \\
\hline
\end{tabular}

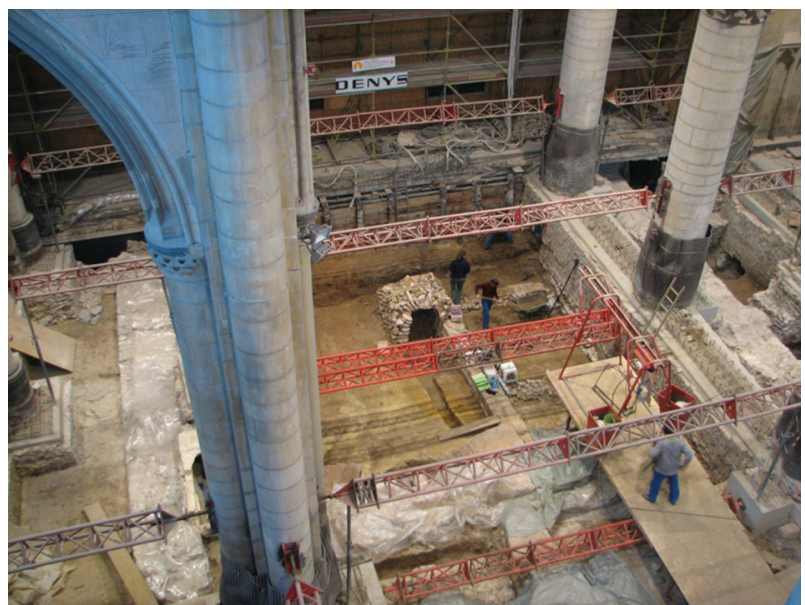

Figure 22 Archaeological excavations under basilica 

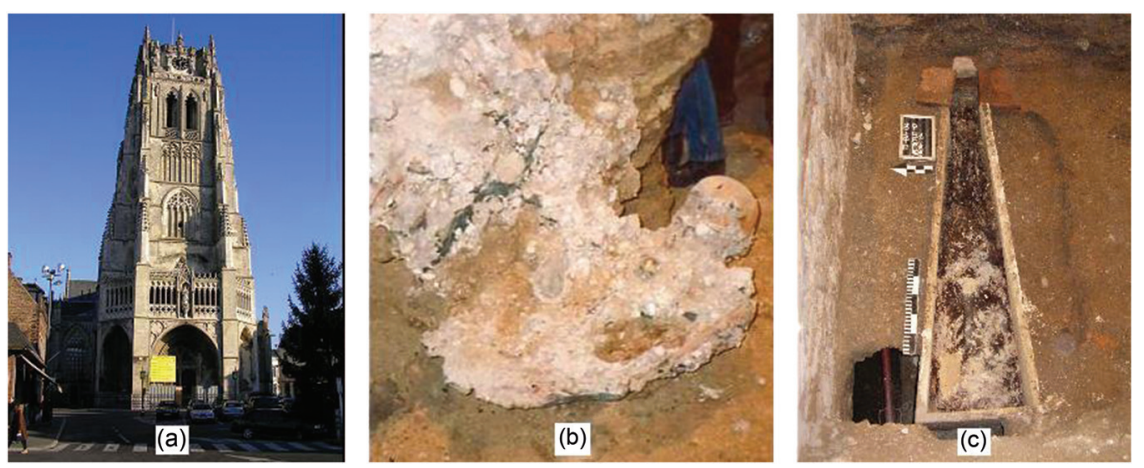

Figure 23 (a): Tower of Our Lady's Basilica at Tongeren (Belgium, tower constructed 1442-1541). (b): unwanted "consolidation" of a skeleton (injected with cement-based grout of phase I). (c): sarcophagus next to the chain wall (excavated in phase II), with partially grouted skeleton

successfully executed with a cement-based grout in the initial phase of the project, there were some disadvantages using this type of grout. Cement-based grouts, developed for the first phase I of the restoration project, tend to remain very fluid for several hours, causing damage. Some valuable inscriptions on lime stone fragments were lost and even a skeleton was accidentally injected (Figure 23(b)).

To prevent accidents as shown in Figure 23(b) and (c), hydrated lime was added to the cement-based grout. Mix compositions are shown in Table 5.

The aim was to develop a mixture that not only satisfied all the requirements needed for structural strength but also limits the fluidity in time. In that way, the unwanted consolidation of valuable artefacts is reduced to a minimum.

\subsubsection{Grout requirements}

Tomazevic et al. [17] and Toumbakari [16] indicated that the mechanical properties of the grout hardly influence the final compressive strength of injected masonry in case of comparable injectability. Adhesion of grout to stone and mortar is more important, see Figure 19 and Table 1. Therefore, it is preferable to focus on rheological properties of the grout and on tensile or adhesion strengths instead of compressive strength. A second category of requirements could be named "compatibility" with the original material. The grout needs to be adapted to the original material with regard to three aspects: chemical (including durability), mechanical/structural and physical compatibility. Special attention is paid to the aspect of historical compatibility keeping in mind the original composition of the mortars.

\subsubsection{Grout development}

In order to fulfil the requirements, it was decided to examine several mixtures of binary grout using cement and air hardening lime as basic materials [19]. Table 5 shows the different mixtures that were tested. Table 5 mentions the W/B (water/binding agent - ratio) instead of the W/C because the binding agent is a mixture of cement and air hardening lime. This W/B and the amount of superplasticizer (Glenium 27, polycarboxylic ether superplasticizer) were kept constant. Practical experience showed that higher amounts of superplasticizer increased shrinkage; lower amounts require too much water [18]. The following mixing procedure was used: dry mixing of cement and calcium hydroxide, addition of $90 \%$ of the water and 2 min mixing (2,400 r/min), after 2 min rest, addition of $5 \%$ water with $50 \%$ of superplasticizer amount and mixing for $3 \mathrm{~min}(2,400 \mathrm{r} / \mathrm{min})$, after $2 \mathrm{~min}$ rest, addition of the final

Table 5 Compositions of the binary grouts for the injections during phase II. Remark: composition 1 is used as a reference, it is the cement-based grout used in phase I

\begin{tabular}{lrrrrrr}
\hline Component & CEM IIIA 42.5 (kg) & Bentonite (kg) & $\mathbf{C a}(\mathbf{O H})_{2}$ (kg) & W/B ratio & Water(liters) & Glenium 27 (kg) \\
\hline Composition 1 & 100 & 2 & & 0.675 & 67.5 & 1 \\
Composition 2 & 50 & & 50 & 0.675 & 67.5 & 1 \\
Composition 3 & 60 & 40 & 0.675 & 67.5 & 1 \\
Composition 4 & 70 & 30 & 0.675 & 67.5 & 1 \\
Composition 5 & 80 & 20 & 0.675 & 67.5 & 1 \\
\hline
\end{tabular}


amount of water (5\%) with the last $50 \%$ of superplasticizer and mixing for $2 \mathrm{~min}(2,400 \mathrm{r} / \mathrm{min})$.

A two-year test program was implemented to study the long-term effects of the grout mixtures of Table 5 . The tests were done on samples $40 \times 40 \times 160 \mathrm{~mm}^{3}$ according to the standard (NBN EN 1015-11 (1999)) for compression and flexural strength. The environmental conditions of the samples were kept constant for the first 90 days at $\mathrm{RH}$ higher than 95\%; $\mathrm{CO}_{2}$-amount 3\% (using a $\mathrm{CO}_{2}$-incubator) and temperature of $20^{\circ} \mathrm{C}$. Then, the samples were divided into two groups $\mathrm{A}$ and $\mathrm{B}$, corresponding to a relative humidity higher than 95\% (group A) and 85\% (Group B) for a two years testing period.

The stability is checked by measuring the bleeding which can be read from the scale on a lab tube in which the grout is poured. The bleeding was measured after $0^{\prime}$, $15^{\prime}, 30^{\prime}, 60^{\prime}, 90^{\prime}$ and $120^{\prime}$. It is concluded that the higher the content of cement, the higher the bleeding will be. Air hardening lime seems to function as a very good stabilizer. Composition 1 produces the most bleeding, but still keeps bleeding under 3\%, which is regarded to be tolerable for grout mixtures. The fluidity test is performed with a Marsh funnel Viscometer (ASTM C 939-(1987)). The Marsh cone (OFI Testing Equipment, item 110-10) is calibrated so that it takes $26 \pm 0.5$ seconds for $947 \mathrm{ml}$ of water $\left(21 \pm 3^{\circ} \mathrm{C}\right)$ to pass the funnel. Figure 24 gives the Marsh cone flow times of the different compositions tested for phase II. The flow times were measured after $0^{\prime}, 15^{\prime}, 30^{\prime}, 60^{\prime}, 90^{\prime}$ and $120^{\prime}$.

As mentioned before, it is the aim to develop a grout whose fluidity stays constant the first one and a half hour and then decreases rapidly. Figure 24 clearly shows that compositions with an air hardening lime content above
$30 \%$ fulfil this special condition needed to prevent the filling of the valuable artefacts. An additional injection test consisted of the injection with grout (composition 3), under a constant pressure of 1 bar, of a plexiglass column, which was filled with gravel (broken bricks). The crushed bricks show a water absorbing action comparable to the real situation. The size of the brick particles varies between $1 \mathrm{~mm}$ and $2 \mathrm{~mm}$. The grout proved capable of consolidating the gravel.

The compressive and flexural strength tests are being executed after 28, 90, 180, 365 and 730 days. Figure 25 gives the evolution of the compressive and flexural strengths of the different compositions of group A, kept at $\mathrm{RH}>95 \%$.

Figure 26 gives the evolution of the compressive and flexural strengths of the different compositions of group B, kept at $\mathrm{RH}=85 \%$.

Higher cement content results in higher compressive strengths. The compressive strength of group B tends to decrease slightly after one year. The flexural strength depends on the amount of cement and on the relative humidity (RH). Group A ( $\mathrm{RH}>95 \%$ ) shows no decrease of the flexural strength after 365 days. For group B, a cement content of $70 \%$ is observed to be a minimum to prevent dropping of the flexural strength after one year. After 2 years there is a drop in flexural strength, also for the compositions with 70 or $80 \%$ of cement. The drop of flexural strength is probably due to microcracking occurring at the interior of the samples. It is assumed that the reason of this microcracking is caused by drying or by the difference between areas of the grout situated toward the exterior of the specimen that are carbonated and other areas towards the interior, that are still hardening. Hydration causes chemical shrinkage and induces tensile stresses (and thus

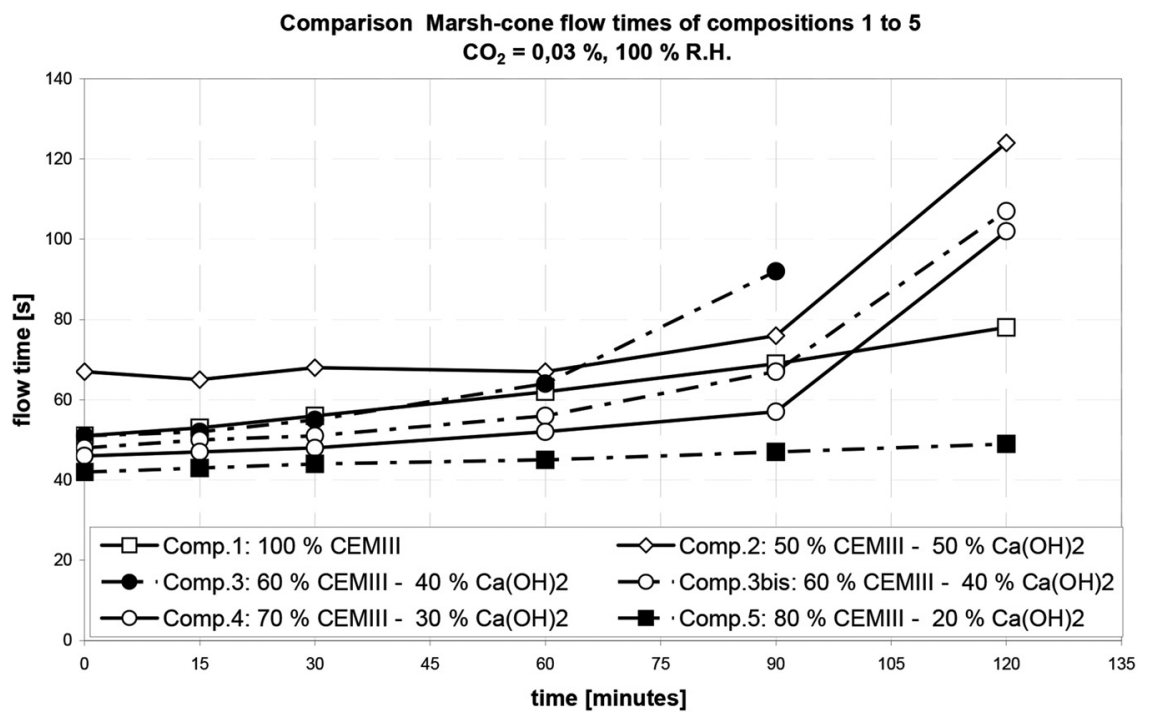

Figure 24 Marsh cone flow times at different times after mixing 
(a) Compressive strength of compositions 1 to 5
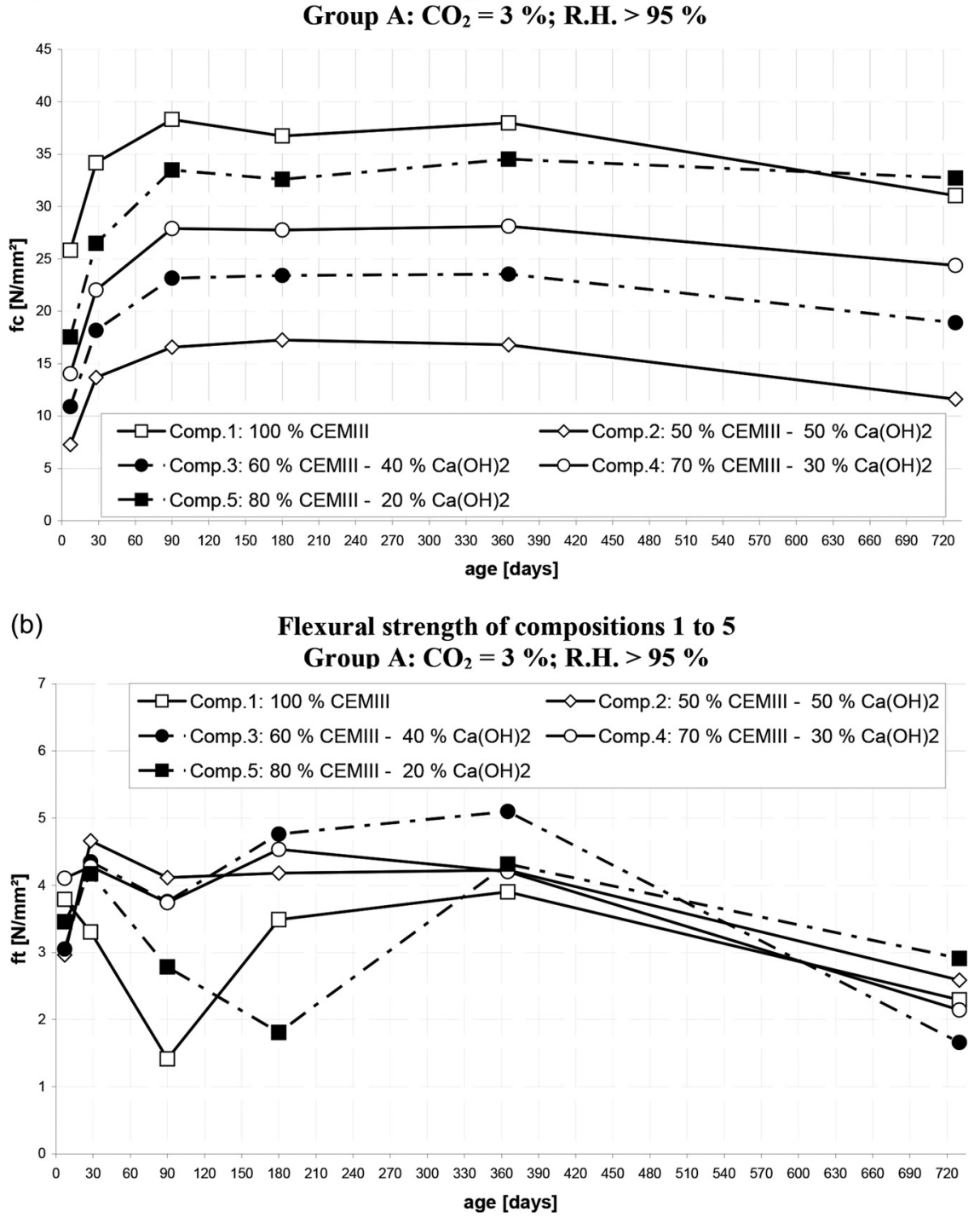

Figure 25 (a) Evolution of compressive strength of group A. (b) Evolution of flexural strength of group A

microcracking) at the interface of a carbonated (and thus inert) part of the material and a not carbonated (and thus hydrating) part of it. A similar phenomenon was already observed and described in [8] for grouts containing pozzolan. After considering all the objectives, it was decided that composition 4 (70\% cement, 30\% slaked lime) corresponded best with all the requirements stated above and therefore was used on site.

\subsubsection{Measures to keep relative humidity above $85 \%$}

During the archaeological excavations, it was observed that the loamy soil fissured due to drying in the atmosphere of the church (Figure 27).
But not only the soil fissured, also the stones of the excavated foundation walls detached from the wall, due to drying and shrinkage of the lime based mortar (Figure 28).

The experience in the test program as well as the observations of cracks on the side made additional humidification necessary. During the excavations, this was realized by covering horizontal wall parts with plastic sheets and by providing jute sheets on vertical wall parts (Figures 29 and 30). The jute sheets were wetted by the contractor at regular times. The level of $\mathrm{RH}$ was monitored manually at the beginning, but since 2005 till today with self-recording sensors. The records were checked to adapt the intensity of wetting of the jute sheets, if needed. 


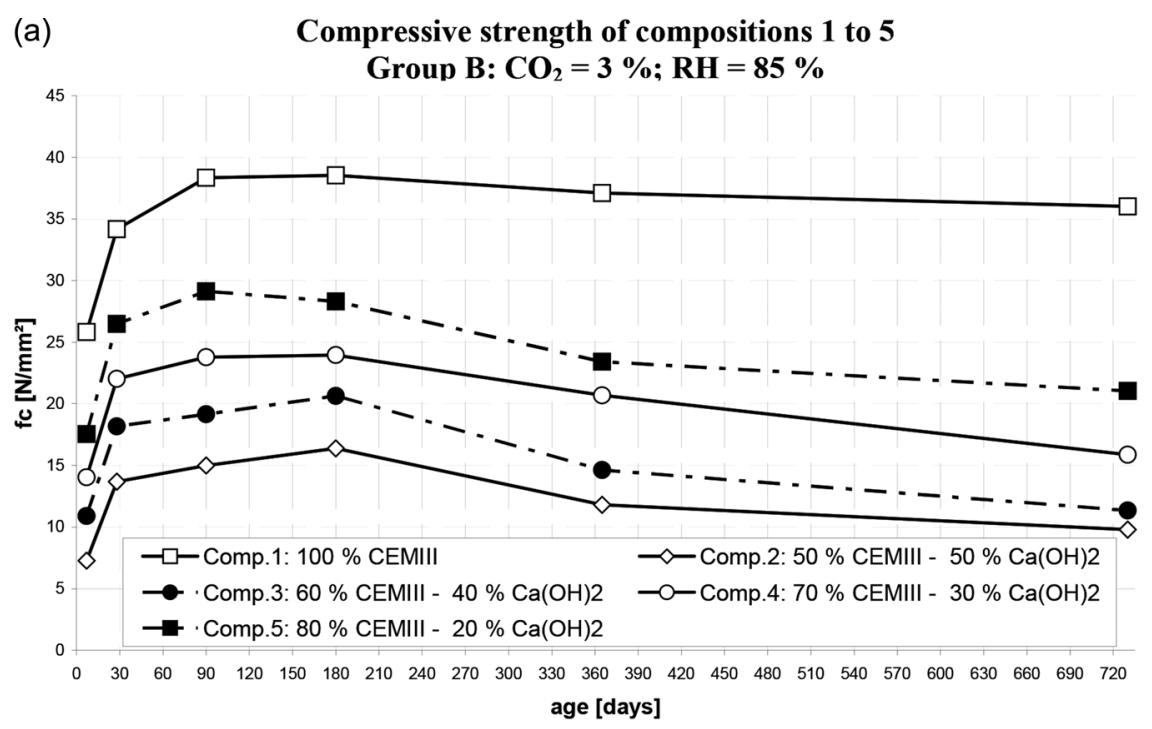

(b)

\section{Flexural strength of compositions 1 to 5

$$
\text { Group B: } \mathrm{CO}_{2}=3 \% ; \mathrm{RH}=85 \%
$$

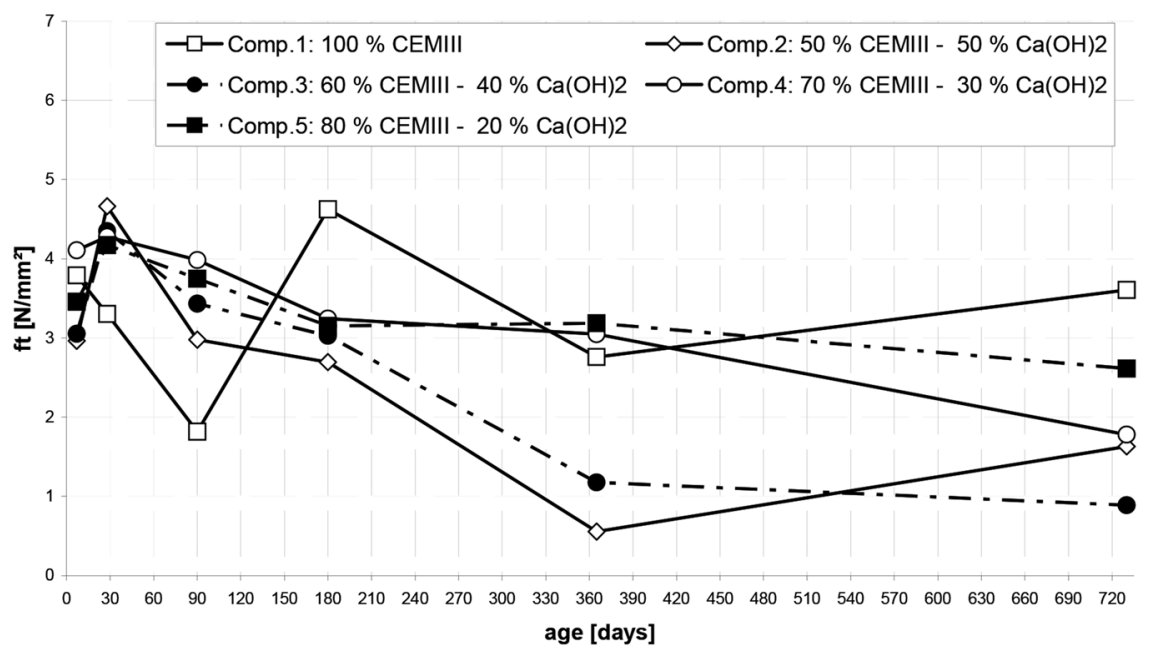

Figure 26 (a) Evolution of compressive strength of group B. (b) Evolution of flexural strength of group B

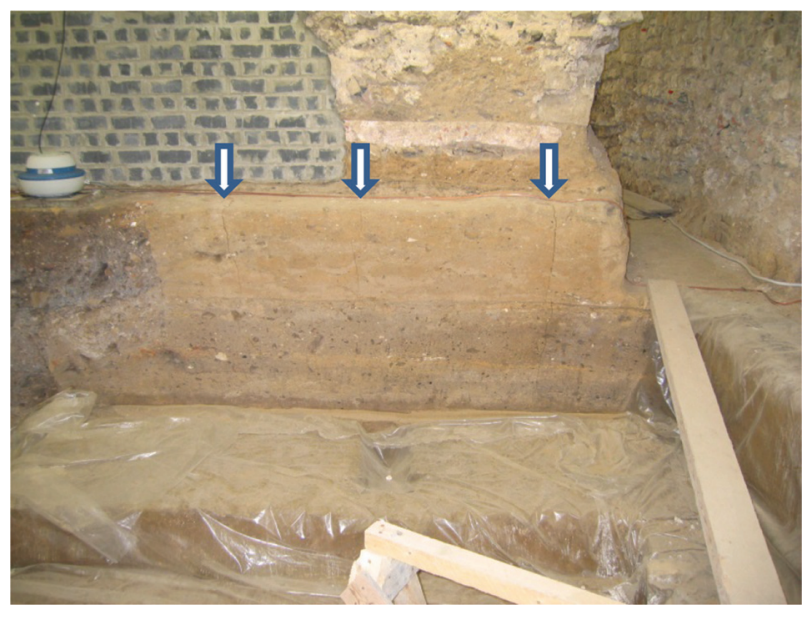

Figure 27 Cracking of loamy soil during excavations inside the church

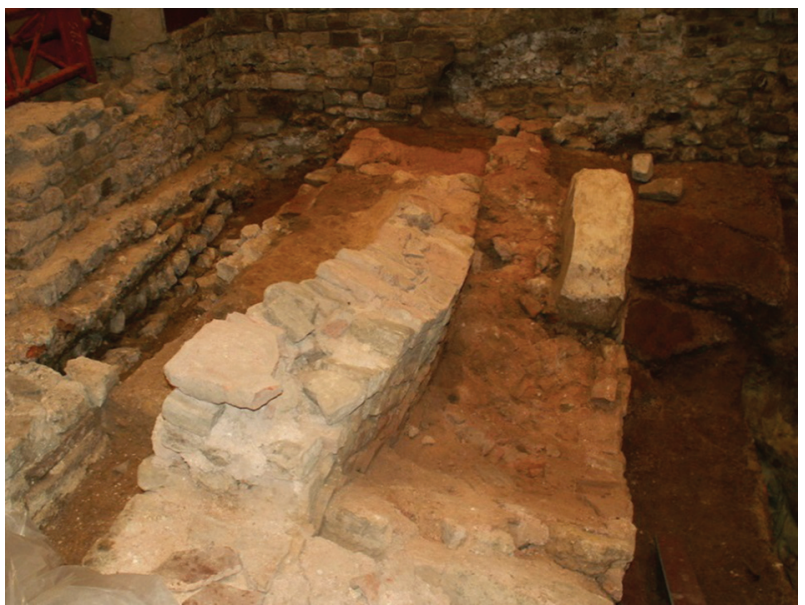

Figure 28 Degradation of foundation remains due to drying and shrinkage of mortar 


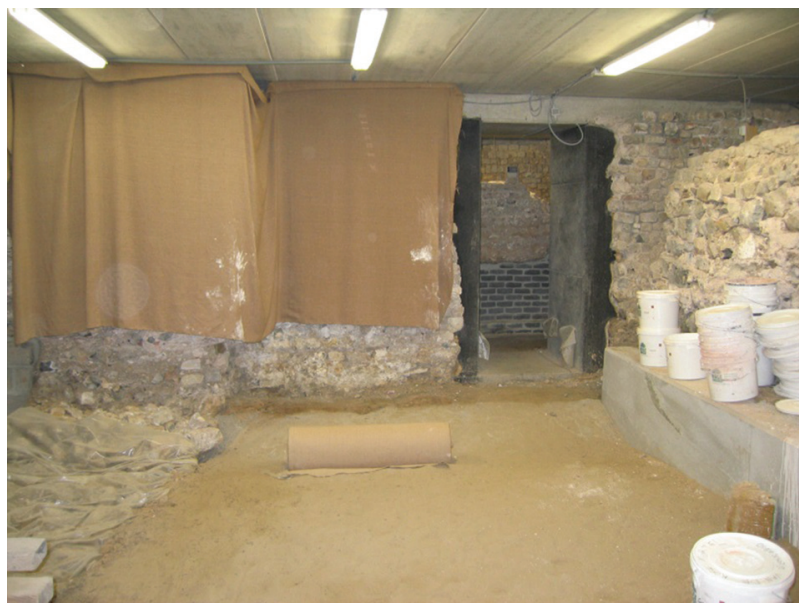

Figure 29 Wet jute sheets to avoid drying of the walls

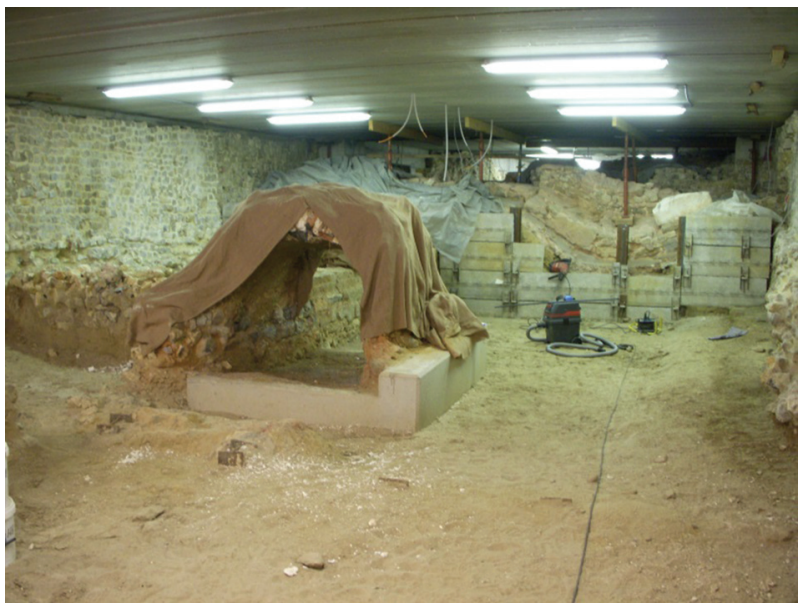

Figure 30 Jute cover on top of excavated arch (see also Figure 22). Cellar partly covered by concrete floor
In the final phase of the project, an HVAC system has been installed to keep humidity in the archaeological cellar above $85 \%$. Monitoring is still going on, showing that temperature control functions well, but relative humidity on average follows the seasons (Figure 31 ).

It may be clear from the figure that regular control of $\mathrm{RH}$ in the cellar is not an unnecessary task. Only in summer times the relative humidity in the cellar meets the requirements, and further tuning of the system is in the pipe-line.

The archaeological cellar is now made accessible for the public (Figure 32).

\section{Conclusions}

Consolidation of historical masonry is based on a thorough knowledge of damage and failure mechanisms in the masonry, as well as on a scientific approach of injection grout composition and of its application. Although extensive research results are already available, the design engineer should stay aware that each historical masonry has its specific properties, and that experimental results may not be generalized nor applied to other historical masonries. Especially in multiple leaf historical masonry classical strengthening techniques with mechanical anchoring might not deliver the normally expected performance. Specific failure mechanisms are active in multiple leaf masonry and must be counteracted in an appropriate way. However, besides physical and mechanical requirements, also conservational requirements are important in the development of an injection grout. If environmental conditions are changed, as it is

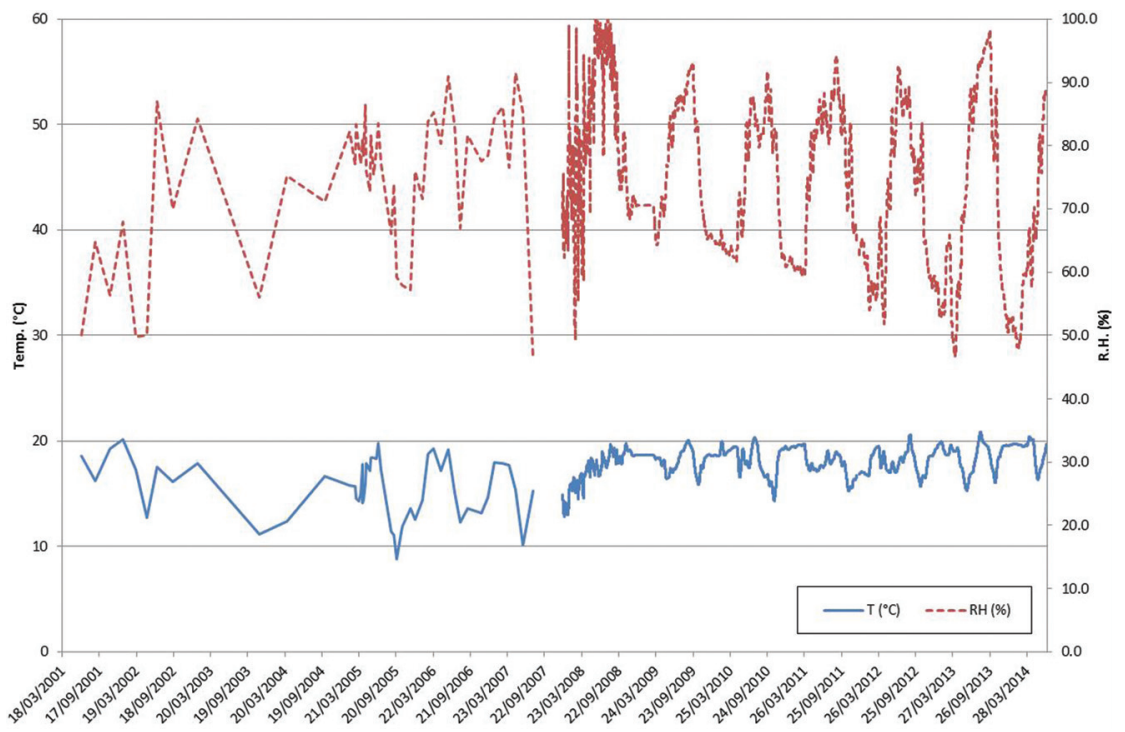

Figure 31 Evolution of RH in the archaeological cellar, period 2001-2014 


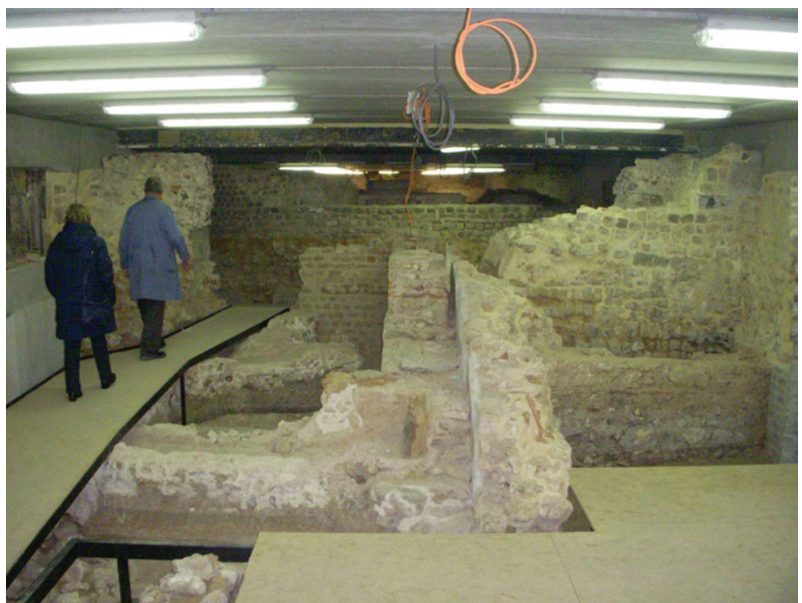

Figure 32 Walkways and platforms for safe and instructive access of visitors

the case in archaeological excavations, lime-based mortars may suffer much more from changing humidity conditions than from changing mechanical actions.

\section{References}

1. Icomos International Council on Monuments and Sites. The Venice Charter 1964-International Charter for the Conservation and Restoration of Monuments and Sites. 2nd International Congress of Architects and Technicians of Historic Monuments, Venice, 1964.

2. Copsey N, Gourley B, Allen R. Mud mortars in masonry construction. Malton, North Yorkshire: Society for the Protection of Ancient Buildings SPAB-News, Heriott-Watt University Edinburgh, 2009.

3. Van Gemert D, Vos P, Ignoul S. Collapse and reconstruction of the tower of the St Willibrordus Church at Meldert Lummen (B). Restor Build Monuments 2014;20:3-24.

4. Bothara J, Brzev S. Improving the seismic resistance of stone masonry buildings. A tutorial, Publication Number WHE-2011-01. Oakland, CA: Earthquake Engineering Research Institute, 2011.

5. Van Gemert D. The use of grouting for the consolidation of historic masonry constructions, stable-unstable. In: Stable Unstable. Structural consolidation of ancient buildings. Lemaire R, Van Balen K, editors. Leuven (Belgium): Leuven University Press, 1988:265-76.

6. The Applied ATC, Council T. Repair of earthquake damaged concrete and masonry wall buildings, Report FEMA 308, California, 1999.

7. Van Gemert D, Ladang C, Carpentier L, Geltmeyer B. Consolidation of the tower of St. Mary's Basilica at Tongeren. Int J Restor Build Monuments 1995;1:371-92.

8. Van Gemert D, Toumbakari E-E, Schueremans L. Konstruktive injektion von historischem mauerwerk mit mineralisch- oder polymergebundenen mörteln. Int J Restor Build Monuments 1999;5:73-98.

9. Van Gemert D, Ignoul S, Van Rickstal F, Toumbakari E, Schueremans L. Evolution of structural consolidation and strengthening of masonry in Belgium: historical overview and case-studies. Int J Restor Build Monuments 2003;9: 339-64.

10. Van Gemert D, Van Rickstal F, Ignoul S, Toumbakari E, Van Balen K. Structural consolidation and strengthening of masonry: historical overview and evolution, MSR VI International Conference Materials Science and Restoration, Karlsruhe 16-18.09.03, Seminar 'Consolidation of Masonry', 16.09.03, Advances in Materials Science and Restoration AMSR 1, 1-20, Aedificatio Publishers, Freiburg, 2003.

11. Van Gemert D, Schueremans L, Keersmaekers R, Verstrynge E. Consolidation of historical masonry constructions (Sanierung historischer Mauerwerksbauten), Leipziger Fachtagung 'Innovationen im Bauwesen - Sanierung und Verstärkung von Massivbauten', 07-08 December 2006. Sanierung und Verstärkung von Massivbauten, Dehn F, Holschemacher K, Tue N, editors. ISBN 978-3-89932-166-1, Göttingen: Hubert \& Co., 2007.

12. Verstrynge E, Schueremans L, Van Gemert D, Hendriks M. Modelling and analysis of time-dependent behaviour of historical masonry under high stress levels. Eng Struct 2010. doi:10.1016/j.engstruc.2010.10.010, 8p

13. Dahman W."Untersuchungen zum Verbessern von Mehrschaligem Mauerwerk", Dissertation TH Karlsruhe, 1985.

14. Toumbakari E, Van Gemert D. Lime-pozzolana-cement injection grouts for the repair and strengthening of three-leaf masonry structures, Proceedings 4th International Symposium on the Conservation of Monuments in the Mediterranean, Rhodos, 6-11 May 1997, Vol. 3, 385-394.

15. Toumbakari E, Van Gemert D, Tenoutasse N, Tassios TP. Effect of mixing procedure on injectability of cementitious grouts. Cem Concr Res 1999;29:867-72.

16. Toumbakari E. Lime-pozzolan-cement grouts and their structural effects on composite masonry walls. PhD thesis K.U.Leuven 2002, $310 \mathrm{p}$.

17. Tomazevic M, Weiss P, Velechovsky T, Apih V. The strengthening of stone masonry walls with grouting. In: Brebbia C, Dominguez J, Escrig F, editors. Proc. STREMA II structural repair and maintenance of historical buildings. Southampton: Computational Mechanics Publ, 1991:215-25.

18. Chandra S, Van Rickstal F, Van Gemert D. Evaluation of cement grouts for consolidation injection of ancient Masonry, Proceedings Nordic Concrete Research Meeting, Göteborg, 1993:353-5.

19. Van Gemert D, Schueremans L, Keersmaekers R, Verstrynge E. Consolidation of historical masonry constructions (Sanierung historischer Mauerwerksbauten), Leipziger Fachtagung 'Innovationen im Bauwesen - Sanierung und Verstärkung von Massivbauten', 07-08 December 2006. Sanierung und Verstärkung von Massivbauten, Dehn F, Holschemacher K, Tue N, editors. ISBN 978-3-89932-166-1, Göttingen: Hubert \& Co., 2007. 